\title{
SOEP
}

SOEPpapers

SOEPpapers
on Multidisciplinary Panel Data Research

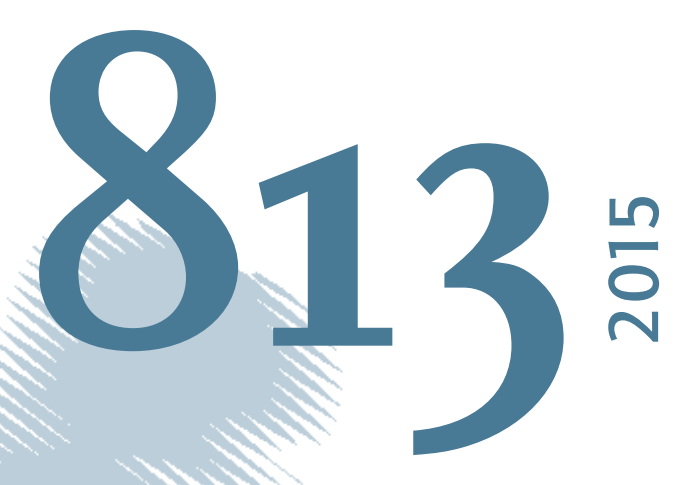

\section{Income in Jeopardy: How Losing Employment Affects the Willingness to Take Risks}


This series presents research findings based either directly on data from the German SocioEconomic Panel study (SOEP) or using SOEP data as part of an internationally comparable data set (e.g. CNEF, ECHP, LIS, LWS, CHER/PACO). SOEP is a truly multidisciplinary household panel study covering a wide range of social and behavioral sciences: economics, sociology, psychology, survey methodology, econometrics and applied statistics, educational science, political science, public health, behavioral genetics, demography, geography, and sport science.

The decision to publish a submission in SOEPpapers is made by a board of editors chosen by the DIW Berlin to represent the wide range of disciplines covered by SOEP. There is no external referee process and papers are either accepted or rejected without revision. Papers appear in this series as works in progress and may also appear elsewhere. They often represent preliminary studies and are circulated to encourage discussion. Citation of such a paper should account for its provisional character. A revised version may be requested from the author directly.

Any opinions expressed in this series are those of the author(s) and not those of DIW Berlin. Research disseminated by DIW Berlin may include views on public policy issues, but the institute itself takes no institutional policy positions.

The SOEPpapers are available at

http://www.diw.de/soeppapers

\section{Editors:}

Jan Goebel (Spatial Economics)

Martin Kroh (Political Science, Survey Methodology)

Carsten Schröder (Public Economics)

Jürgen Schupp (Sociology)

Conchita D'Ambrosio (Public Economics)

Denis Gerstorf (Psychology, DIW Research Director)

Elke Holst (Gender Studies, DIW Research Director)

Frauke Kreuter (Survey Methodology, DIW Research Fellow)

Frieder R. Lang (Psychology, DIW Research Fellow)

Jörg-Peter Schräpler (Survey Methodology, DIW Research Fellow)

Thomas Siedler (Empirical Economics)

C. Katharina Spieß (Education and Family Economics)

Gert G. Wagner (Social Sciences)

ISSN: 1864-6689 (online)

German Socio-Economic Panel (SOEP)

DIW Berlin

Mohrenstrasse 58

10117 Berlin, Germany

Contact: Uta Rahmann | soeppapers@diw.de

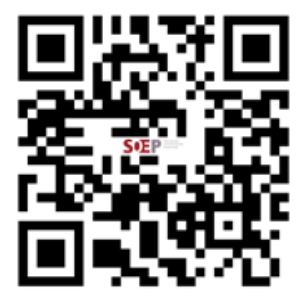


Income in Jeopardy:

How Losing Employment Affects the Willingness to Take Risks

Clemens Hetschko, Malte Preuss*

Freie Universität Berlin

December 15, 2015

\begin{abstract}
Using German panel data, we assess the causal effect of job loss, and thus of an extensive income shock, on risk attitude. In line with predictions of expected utility reasoning about absolute risk aversion, losing one's job reduces the willingness to take risks. This effect strengthens in previous hourly wage, begins to manifest itself as soon as an employee perceives the threat of job loss and is of a transitory nature. The change in stated risk attitude matches observable job finding behaviour, confirming the behavioural validity of our results.
\end{abstract}

JEL Classification: D81; J64; J65

Keywords: absolute risk aversion; income shock; job loss; plant closure; general risk attitude

${ }^{*}$ Corresponding author. Freie Universität Berlin, School of Business and Economics, Boltzmannstraße 20, D14195 Berlin, E-mail: malte.preuss@fu-berlin.de.

\title{
Acknowledgements
}

We are grateful for comments made by Ronnie Schöb, Daniel Nachtigall and seminar participants at the University of Potsdam (2015), the SOEP group (Berlin, 2015) and the Max Planck Institute for Tax Law and Public Finance (Munich, 2015). We also thank participants of the Trier Workshop in Economics (2015), the $5^{\text {th }}$ Workshop in Labour Economics and Social Policy (Dresden, 2015), the $1^{\text {st }}$ BeNA Labour Economics Workshop (2015), the $1^{\text {st }} \mathrm{PhD}$ Conference in Behavioural Science (Stirling, 2015), the IAREP/ SABE Joint Conference (Sibiu, 2015) and the $5^{\text {th }} \mathrm{PhD}$ Workshop in Empirical Economics (Potsdam, 2015). Malte Preuss is grateful for financial support from the DFG through SFB-TR 15. 


\section{Introduction}

The willingness to take risks strongly affects economically important outcomes such as entrepreneurial activity, migration and households' allocation of financial assets. Some part of individual risk attitude is rooted in genetic dispositions, socialisation and personality development. ${ }^{1}$ Beyond that, life experiences such as poverty (e.g. Haushofer and Fehr 2014), child birth (Görlitz and Tamm 2015) or being exposed to violence (Callen et al. 2014) shape people's willingness to take risks. The Great Depression (Malmendier and Nagel 2011) and natural disasters have been shown to increase risk aversion, probably because the appearance of a rare event amplifies its general perception (Cameron and Shah 2015, Goebel et al. 2015). We analyse the risk-taking effect of another source of substantial individual risk concerning the vast majority of employees in market economies: losing one’s job. As approaching and experiencing job loss places, first and foremost, workers' current and future income in jeopardy, this event facilitates a natural experiment for studying the impact of an extensive income shocks on risk attitude.

Previous research does not come up with clear answers on how a negative income shock may alter individual risk attitude. Brunnermeier and Nagel (2008) find that fluctuations in household wealth do not yield any adjustment in risk-taking with respect to households' asset allocations, probably because of inertia. Post et al. (2008) analyse repeated decisions of people gambling in the TV show 'Deal or No Deal?' and conclude that risk aversion increases after both belied and excelled expectations. Both Brunnermeier and Nagel (2008) as well as Post et al. (2008) use data on choices to reveal risk attitude. In principle, other dominant factors (like inertia) related to these choices may veil the direct impact of a financial gain or loss on general risk attitude, which potentially affects all individual choices. In contrast, we provide evidence on the effect of an income shock on a direct measure of risk attitude.

To the best of our knowledge, Sahm (2012) provides the only existing study on the impact of job loss on risk attitudes. Besides various other insights pointing to time-invariant risktaking, she does not find that elder workers in the US change risk attitude in the wake of being dismissed. In contrast to her, we focus on job losses due to the closure of a complete plant or firm and thus on a much more specific type of dismissal. This is for two reasons: First, many dismissals may often be preventable by the worker (dismissal due to misconduct

\footnotetext{
1 See Cesarini et al. (2010), Mata et al. (2012) as well as Harrati (2014) on genetic disposition. See Dohmen et al. (2012) as well as the review of Becker et al. (2012) on sozialisation and personality development.
} 
or shirking) and therefore result from given risk attitude rather than causing a change in risk attitude. Second, the impact of dismissals for any reason may not generalise to the average risk-taking effect of job loss since the affected subgroup of workers (low-skilled, health problems) does not represent the workforce well.

To the extent that workers cannot insure the income risk associated with non-controllable job loss, its impact on risk attitude will be that of a background risk. Public insurances replace wage income only to some extent, and then only for a limited period of time. They do not account for the loss of company pensions, the scarring effects of unemployment (reduced earnings when reemployed, e.g. Arulampalam et al. 2001) and the loss of non-monetary welfare (e.g. reductions of social participation and identity utility, see Kunze and Suppa 2014, Hetschko et al. 2014). As a result, we argue that increasing risk of job loss will cause workers to avoid other controllable risks more often as decreasing absolute risk aversion (DARA) characterises their utility function. ${ }^{2}$

To test this notion by estimating the causal effect of loss of work on risk attitude, we apply a difference-in-differences approach based on German Socio-economic Panel data (SOEP). We assign workers who experience job loss due to the closure of the complete plant or company to the treatment group and similar employees who do not lose their jobs to a control group. ${ }^{3}$ As a behaviourally valid measure of general risk attitude, we use the stated willingness to take risks. It turns out that exogenous job loss indeed decreases the willingness to take risks. The effect already begins to manifest itself before the job loss event ultimately occurs, as workers may perceive that employment is increasingly at risk. Pre-treatment hourly wage as proxy for the losses of earnings and nonwage benefits associated with job loss amplifies the negative impact of job loss on risk-taking. This confirms that the losses of current income and the fear of losing future income are driving forces behind the impact of job loss on risk-taking. In the aftermath of the event, the willingness to take risks gradually returns to its initial level as workers become reemployed. This suggests that the risk attitude effect of losing work is of a transitory nature. The appearance of job loss does not seem to change the future perception of this specific risk or of other calamities. Additional empirical analyses point to the behavioural validity and economic significance of our findings.

\footnotetext{
2 DARA is not only an intuitive, but also an often empirically proven assumption (see, e.g., Bombardini and Trebbi (2012) as well as Guiso and Paiella (2008).

${ }^{3}$ We hereby follow, inter alia, Kassenboehmer and Haisken-DeNew (2009), Schmitz (2011), Marcus (2013).
} 
Our findings not only complement the literature on the origins of risk-taking, they also concern the theoretical foundation of the increasingly popular general risk attitude measure we use. ${ }^{4}$ Job loss affects the willingness to take risks in the way predicted for absolute risk aversion. We therefore recommend using the survey item accordingly. While our study shows that this measure responds to certain life events, it should not be implied that general doubts about the theoretical assumption of time-invariant general risk preferences, which reflect the shape of the utility function, are justified. Empirical researchers should, however, be aware of the fact that the general risk attitude measure is not exogenous to living conditions and life experiences. In consequence, if the willingness to take risks is examined regarding its effect on any outcome, researchers must consider simultaneity bias.

We proceed as follows. Section 2 applies expected utility reasoning to derive theoretical hypotheses about the impact of job loss on risk attitude. In Sections 3 and 4, we describe our identification strategy, data and sampling. Section 5 documents the results of our empirical analyses and finally Section 6 concludes and discusses our findings.

\section{Theoretical background and hypotheses}

Consider an individual $i$ with a von Neumann-Morgenstern utility function $u\left(w_{i}, \tilde{y}_{i}\right)$ that describes utility received from future 'labour income' $w_{i}$, and a non-insurable income loss $\tilde{y}_{i}$. Both are defined broadly and can consist of wage and nonwage job characteristics. $w_{i}$ results from expectations concerning the benefits of working, adjusted by any risk they can influence. In contrast, job loss will concern $\tilde{y}_{i}$ when employees can neither influence its probability, such as in the case of plant closure, nor insure themselves comprehensively. As argued in the introduction, a significant part of the individual welfare loss associated with job loss may be non-insurable. We therefore consider exogenous job loss hereinafter as immutable and non-insurable background risk.

Two elements shape the risk of job loss. Its probability $J L \sim P\left(J L \mid \omega_{t}\right)$, which depends on the set of information $\omega_{t}$ pointing to job loss at a point in time $t$ and the total damage $v_{i}$ resulting from job loss. Abstracting from any other immutable risk, the total expected loss from job loss is $\tilde{y}_{i}=P\left(J L \mid \omega_{t}\right) \cdot v_{i}$. The set of information changes when new information about

\footnotetext{
${ }^{4}$ For primarily methodological discussions of the survey item see Dohmen et al. (2011) and Charness et al. (2013). For recent applications of the item see, for instance, Pannenberg (2010), Jaeger et al. (2010), Dohmen et al. 2012, 2015a, 2015b, Brachert and Hyll (2014), Skriabikova et al. (2014), Fossen and Glocker (2014), Görlitz and Tamm (2015), Schurer (2015), Goebel et al. (2015).
} 
a job loss arrive. If job loss becomes absolutely certain, $P\left(J L \mid \omega_{t=-2}\right)<P\left(J L \mid \omega_{t=0}\right)=1$ with $\omega_{t=-2}$ as information set way before the actual job loss takes place and $\omega_{t=0}$ as set of information right after the job loss has occurred. To assess the influence of job loss on risk attitude, we measure its theoretical effect on absolute risk aversion in the spirit of Arrow and Pratt. Following Kihlstrom et al. (1981) and Nachman (1982), the presence of a background risk renders

$$
\operatorname{ARA}\left(w_{i}-\tilde{y}_{i}\right)=-\frac{E u^{\prime \prime}\left(w_{i}-\tilde{y}_{i}\right)}{E u^{\prime}\left(w_{i}-\tilde{y}_{i}\right)} .
$$

In consequence, the shift in $\omega_{t}$ increases the expected loss from job loss for the next considered period. By assuming $u\left(w_{i}, \tilde{y}_{i}\right)$ to imply DARA, an increase in immutable risk raises the level of absolute risk aversion (Pratt and Zeckhauser 1987, Kimball 1993, Eeckhoudt et al. 1996).

\section{Hypothesis 1: Job loss increases the level of ARA.}

Workers may anticipate job loss from a certain point in time onwards. Lacking competiveness of the firm, rumours, mass layoffs, or, at the very end, insolvency proceedings may trigger, step by step, an update in the information set. The shift in $\omega_{t}$ is therefore not a strict binary change, but a gradual or iterative process till $t=0$ is reached, i.e. $P\left(J L \mid \omega_{t=-2}\right)<P\left(J L \mid \omega_{t=-1}\right)<P\left(J L \mid \omega_{t=0}\right)$. Hence, the job loss probability is likely to grow slowly with new arriving information, causing an early update in expectations and, therefore, in ARA, too.

Hypothesis 2: ARA gradually increases before job loss occurs.

The more time has passed by after a job loss event, the more workers will be observed to be reemployed. However, job search takes some time and a new job often starts with probation or a fixed-term contract, keeping uncertainty about employment stability and thus uncertainty about future incomes at a high level. In short, job loss is still increasing ARA compared to the time before the event even when workers have recently started a new job. As time goes by, however, employees establish themselves in the new job and gather new information about the next involuntary job loss. The new set of information after re-entering employment and passing the new job's uncertainty $\left(\omega_{t=1}\right)$ should imply a similar job loss prospect as $\omega_{t=-2}$ does $\left(P\left(J L \mid \omega_{t=-2}\right) \approx P\left(J L \mid \omega_{t=1}\right)\right)$. Hence, the job loss probability shifts back and so does ARA. 
Hypothesis 3: ARA gradually returns towards its initial level after job loss occurred.

In addition, we expect heterogeneous effects. As already indicated by the index $i$, labour market income and expected loss differ between individuals due to individual resources. Workers who have high levels of education, for instance, earn higher wages than less educated workers and thus stand to lose much more, both in terms of future income and in terms of other benefits of employment (e.g. status), in the case of job loss. In the following, we refer to those highly paid employees as high-skilled workers $(i=h)$ and to workers with relatively low wages are referred to as low-skilled workers $(i=l)$. The heterogeneity results in $w_{h}>w_{l}$ and $v_{h}>v_{l}$. Assuming the same change in the set of information for both types, the inequality in individual damage will yield $\Delta \tilde{y}_{h}>\Delta \tilde{y}_{l}$ with $\Delta \tilde{y}_{i}=\left(P\left(J L \mid \omega_{t=0}\right)-P\left(J L \mid \omega_{t=-2}\right)\right) \cdot v_{i}$, when an exogenous job loss becomes more likely and finally occurs. Whether this leads to a bigger change in ARA for high skilled individuals depends on the utility function and the inequality in expected income. By assuming DARA, a marginal change in income leads to $\partial \operatorname{ARA}\left(w_{h}-\tilde{y}_{h}\right) / \partial(w-\tilde{y}) \leq \partial \operatorname{ARA}\left(w_{l}-\tilde{y}_{l}\right) / \partial(w-\tilde{y}) \quad$ if $w_{h}-\tilde{y}_{h} \geq w_{l}-\tilde{y}_{l}$ holds. Hence, $\Delta \tilde{y}_{h}>\Delta \tilde{y}_{l}$ resolves in a greater change in ARA for $h$-types only if three conditions are fulfilled: First, the difference in income is sufficiently small. Second, ARA is only weakly convex, i.e. $\partial^{2} \operatorname{ARA}\left(w_{h}-\tilde{y}_{h}\right) / \partial(w-\tilde{y})^{2}$ is close to zero. And last, $\Delta \tilde{y}_{h}-\Delta \tilde{y}_{l}$ is sufficiently big.

Hypothesis 4. Job loss changes ARA of high-skilled workers more than ARA of low-skilled workers.

\section{Data}

Our analysis is based on ten waves (2004-2013) of German Socio-economic Panel (SOEP) data (SOEP 2015, Wagner et al. 2007). Each year, roughly 20,000 individuals living in 11,000 households provide information about manifold personal perceptions and attitudes, their employment status, income, health and much more. The time interval between two SOEP interviews is approximately one year. Because of its panel structure and the opportunity to analyse exogenously triggered job losses (plant closure) as well as the availability of a continuously repeated question on the willingness to take risks, the SOEP stands out when compared with other comparable representative panel data sets regarding the purposes of this study. 
As an inverse measure of ARA, we use the following question on general risk attitudes (GRA) that is measured in 2004, 2006 and each year from 2008 onwards:

Would you describe yourself as someone who tries to avoid risks (risk-averse) or as someone who is willing to take risks (risk-prone)? Please answer on a scale from 0 to 10, where 0 means "risk-averse" and 10 means "risk-prone".

According to the findings of Dohmen et al. (2011) as well as Fossen and Glocker (2014), people answer in line with alternative measurements of risk attitudes (risk attitudes revealed through decisions under uncertainty, such as real-stake lotteries, holding stocks, being selfemployed, educational choices). Thus, the item can be considered a behaviourally valid measure of risk attitude, which we will discuss further with respect to our results in Section 5.5. As risk attitudes seem to differ to some extent between areas of life, our measure may be even better suited to ascertain risk attitude than hypothetical or actual lotteries and gambles, which confront respondents with a very specific situation.

When workers have terminated an employment relationship between two SOEP interviews, they are asked about the specific reason: 'How did that job end?'. Answers that the 'office or place of work has closed' (plant closure in the following) identify exogenously triggered job losses best. At two points, we make also use of data about other dismissals ('I was dismissed by my employer') to show how including more endogenous reasons for job loss would affect our results. Further possible answers to the question on terminated employment are not considered, namely a notice of resignation, mutual agreement with employer, the end of a temporary contract, retirement or taking a leave of absence, maternity leave or parental leave.

The sample we analyse consists of initially 'regular' employees only. They are either fulltime or part-time employed and spend more than 15 hours per week working, which is the legal threshold between marginal employment and regular employment in Germany. Observations of self-employed workers are not considered. ${ }^{5}$ However, we do not restrict the sample with respect to workers' labour market activities after job loss has taken place. Besides having taken up a new regular employment, they can be unemployed, have left the workforce, or are doing anything else (e.g. occasional jobs). Not being selective at this point

\footnotetext{
${ }^{5}$ We do not exclude public sector employees although they are much less likely to experience plant closure than private sector employees. However, excluding public sector would not yield results that are different from those presented in the following.
} 
avoids any systematic bias by sampling. Unemployment duration analyses will distinguish between employment states after job loss (Section 5.5). Our sample is limited to workers who are older than 20 years, but younger than 65 years. For our investigation period that is restricted by the availability of the GRA measure, we can observe 37,700 observations of regular employees, of which 239 experience job loss for the reason of plant closure.

Some individual characteristics are used to identify high-skilled individuals (named h-type in Section 2) and low-skilled individuals (l-type) in order to test our fourth hypothesis. First, we compute the individual hourly gross wage. It is based on information of actual weekly working hours and gross monthly labour income. Second, we use two discrete measurements of individual skills. Education is classified according to the ISCED-97 scale. l-types have no more than secondary education (up to ISCED-97 level 3, which is the median level). h-types are educated at least at ISCED-97 level 4 (anything beyond secondary education). As another alternative, we identify people as $h$-types that have above-median autonomy in occupational actions, such as managers (below-median autonomy as l-types).

Beyond that, we utilise data on various further socio-demographic characteristics (age, net household income adjusted by OECD equivalent weights, overall lifetime unemployment experience to date in years, gender, marital status, children living in household, marital status, migration background) and job characteristics (gross hourly wage in Euros, tenure in years, level of occupational autonomy, company size, daily working hours, part-time employment, public sector employment, sector of industry). Finally, we merge our data with precise 'INKAR' (indicators of the development of cities and regions) information about unemployment rates of the 96 German planning regions (Raumordnungsregionen, see BBSR 2015).

\section{Empirical identification}

To test our hypotheses, we apply a difference-in-differences approach to identifying the effect of exogenous job loss on the general willingness to take risks. The treatment group of regular employees lose their jobs for the reason of plant closure between two SOEP interviews, which we refer to as $t=-1$ and $t=0$ in the following. Accordingly, we assume that plant closures occur independent of workers' characteristics. We discuss this assumption and provide evidence for its validity in the course of our robustness analysis (Section 5.6). Job loss may often bring about job insecurity in $t=-1$ which means that the treatment might affect the willingness to take risks already at this point in time. Our pre-treatment reference point is 
hence $t=-2$, which means that we assume that workers do not anticipate the plant closure event if it takes place at least one year later. A control group of regular employees is included in order to control, for instance, for time trends explaining changes in the willingness to take risks. This group does not experience a job loss and stays employed at least for the duration of three SOEP interviews in a row, which equal $t=-2, t=-1$ and $t=0$.

We impute missing answers to the willingness to take risks question in $t=-2$ by the previous interview $(t=-3)$, if the individual is observed as employed in this specific period. The setting requires that members of the treatment and the control group continue to participate in the survey for at least three interviews in a row. Given this and all the other restrictions (such as the availability of data on individual characteristics taken into account in the following analyses), our sample includes 239 observations in the treatment group and 37,461 observations in the control group.

The treatment effect that allows us to test our first hypothesis is the difference between treatment and control group in the within-group change of the willingness to take risks between $t=-2$ and $t=0$. To be able to consider time effects, we employ a regression approach explaining the change in general risk attitude $(\triangle G R A)$ between the two points in time, dependent on the treatment (dummy Loss $=1$, control group: Loss $=0$ ) and the year of $t=0(Y)$. We include vectors of controls for pre-treatment (measured at $t=-2$ ) sociodemographic characteristics (SD), job characteristics (JC) and parallel life events (Shocks between $t=-2$ and $t=0$ ) that account for non-random treatment and help us to approach the true average treatment effect. The empirical model can be written as

$$
\Delta G R A_{i}=\alpha+\beta \text { Loss }_{i}+\gamma^{\prime} S D_{i}+\delta^{\prime} J C_{i}+\sigma^{\prime} \text { Shocks }_{i}+\theta^{\prime} Y_{i}+\varepsilon_{i}
$$

with $\alpha$ as the average change of the general risk aversion of the reference group and $u_{i}$ as the error term. Consequently, sign and significance of the $\beta$-coefficient provide us with evidence regarding Hypothesis 1. Subgroup analyses will clarify whether the corresponding regression results vary by gender, age or employment status in $t=0$.

Hypothesis 2 suggests decreasing GRA awhile for some time directly before job loss. We therefore test whether a negative effect of $\operatorname{Loss}_{i}$ appears when we estimate $\triangle G R A$ as the difference between the two pre-treatment points in time $t=-2$ and $t=-1$. Regarding reversion of the potential job loss effect on risk-taking (Hypothesis 3), we define the change in GRA between $t=-2$ to $t=1$ as dependent variable. In addition, we can test whether the 
willingness to take risks of treatment and control group follow a common trend before the treatment takes place by estimating $\triangle G R A$ between $t=-3$ to $t=-2$.

According to Hypothesis 4, an effect of job loss on the absolute risk aversion is supposed to be driven by high-skilled workers, which we approximate by pre-treatment gross hourly wage, education and level of educational autonomy (Section 3). To examine the role of these characteristics, it is not sufficient to test whether adding them to (1) alters $\beta$. If Hypothesis 4 holds, a variation in skills plays a different role for the treatment group than for the control group: high-skilled treated are exposed to a bigger income loss than low-skilled ones, when a job loss arises. As discussed in Section 2, this implies a heterogeneity of the subsequent change in GRA within this group, i.e. $\triangle G R A$ should vary by pre-treatment skills. In contrast, if no additional threats arise the level of income risk should have no effect on $\triangle G R A$. Therefore, the level of skills will have a different impact on the change in GRA between treatment and control group. We therefore need to estimate interaction effects of proxies for skills and Loss $_{i}$ in order to examine whether skills matter to the risk attitude effect of losing work. The best representation of individual productivity and, hence, future income and employment prospects, may be one's (pre-treatment) gross hourly wage $\left(W^{2} e_{i}\right)$. We therefore modify (1) and estimate

$$
\begin{aligned}
\Delta G R A_{i}= & \alpha+\beta_{1} \text { Loss }_{i}+\beta_{2}\left(\text { Loss }_{i} \times \text { Wage }_{i}\right)+\beta_{3} \text { Wage }_{i} \\
& +\gamma^{\prime} \text { SD }_{i}+\delta^{\prime} J C_{i}+\sigma^{\prime} \text { Shocks }_{i}+\theta^{\prime} Y_{i}+\varepsilon_{i}
\end{aligned}
$$

In addition, we test interactions of the treatment dummy with education and autonomy in occupational actions as further proxies for individual productivity.

\section{Results}

\subsection{Mean analyses}

As a first step of our difference-in-differences analysis, we compare the average two-year change from $t=-2$ to $t=0$ in the general willingness to take risks between treatment and control group (see Table 1). It turns out that job loss is indeed accompanied by a 0.4 point stronger reduction in willingness to take risks than staying employed $(p<0.05)$. Moreover, the descriptive figures do not imply a selection into the treatment by relatively risk-averse or relatively risk-prone people as the pre-treatment level of GRA does not differ significantly between the two groups. 
The figures imply that the treatment is not completely random. Members of the control group receive higher wages and have more household income available, can act more autonomously in their firms, work in bigger firms, work less hours and are less likely to work in the private sector than people who experience job loss about one to two years later. In addition, job loss due to plant closure is more prevalent in some industries, such as services, than in others. All further characteristics presented in Table 1 do not concern one of the two groups more significantly than the other.

Table 1: Descriptive statistics

\begin{tabular}{|c|c|c|c|c|c|c|}
\hline \multirow{3}{*}{ Number of observations: } & \multirow[t]{3}{*}{ Scale } & \multicolumn{2}{|c|}{ Treatment group } & \multicolumn{2}{|c|}{ Control group } & \multirow{3}{*}{$\begin{array}{c}\text { Difference } \\
\\
\text { test } \\
\text { p-value }\end{array}$} \\
\hline & & \multicolumn{2}{|c|}{239} & \multicolumn{2}{|c|}{37,461} & \\
\hline & & $\begin{array}{l}\text { mean/ } \\
\text { share }\end{array}$ & $\begin{array}{l}\text { standard } \\
\text { deviation }\end{array}$ & $\begin{array}{l}\text { mean/ } \\
\text { share }\end{array}$ & $\begin{array}{l}\text { standard } \\
\text { deviation }\end{array}$ & \\
\hline \multicolumn{7}{|l|}{ Willingness to take risks } \\
\hline GRA (pre-treatment, mean) & $0-10$ & 4.77 & 2.19 & 4.64 & 2.13 & 0.356 \\
\hline Change in GRA (mean) & & -0.39 & 2.22 & -0.09 & 2.19 & 0.034 \\
\hline \multicolumn{7}{|l|}{ Pre-treatment socio-demographic characteristics } \\
\hline Age in years (mean) & & 44.92 & 9.49 & 43.73 & 9.67 & 0.747 \\
\hline Monthly net household income in Euros (mean) & & 1,612 & 686.63 & 1,843 & 979.99 & 0.000 \\
\hline Educational level (mean) & $1-6$ & 3.64 & 1.29 & 4.04 & 1.44 & 0.000 \\
\hline Years of unemployment (mean) & & 0.54 & 1.17 & 0.43 & 1.12 & 0.132 \\
\hline Local unemployment rate (mean) & & 0.09 & 0.04 & 0.09 & 0.04 & 0.310 \\
\hline Men (share) & & 0.62 & & 0.56 & & 0.079 \\
\hline Child in household (share) & & 0.37 & & 0.35 & & 0.646 \\
\hline Married (share) & & 0.68 & & 0.64 & & 0.274 \\
\hline Migration background (share) & & 0.15 & & 0.09 & & 0.010 \\
\hline East Germany (share) & & 0.26 & & 0.24 & & 0.441 \\
\hline \multicolumn{7}{|l|}{ Parallel life events (shares) } \\
\hline New job & & 0.62 & & 0.10 & & 0.000 \\
\hline Divorce & & 0.03 & & 0.01 & & 0.135 \\
\hline Separation & & 0.04 & & 0.03 & & 0.496 \\
\hline Death of spouse & & 0.00 & & 0.00 & & 0.681 \\
\hline Marriage & & 0.04 & & 0.04 & & 0.622 \\
\hline Child birth & & 0.04 & & 0.03 & & 0.681 \\
\hline Move (change of flat/house) & & 0.03 & & 0.03 & & 0.919 \\
\hline \multicolumn{7}{|l|}{ Pre-treatment job characteristics } \\
\hline Monthly net wage in Euros (mean) & & 14.51 & 7.33 & 16.32 & 8.38 & 0.000 \\
\hline Tenure in years (mean) & & 12.18 & 9.64 & 12.93 & 10.03 & 0.229 \\
\hline Level of occupational autonomy (mean) & $1-5$ & 2.60 & 1.00 & 2.94 & 1.06 & 0.000 \\
\hline Company size (mean) & $1-3$ & 2.12 & 0.83 & 2.33 & 0.77 & 0.000 \\
\hline Weekly working hours (mean) & & 41.48 & 9.02 & 40.86 & 9.54 & 0.285 \\
\hline Part time contract (share) & & 0.16 & & 0.18 & & 0.285 \\
\hline Public sector (share) & & 0.07 & & 0.32 & & 0.000 \\
\hline \multicolumn{7}{|l|}{ Sector of industry (shares, sum $=1.00)$} \\
\hline Extraction, exploitation & & 0.02 & & 0.04 & & 0.006 \\
\hline Production & & 0.32 & & 0.26 & & 0.039 \\
\hline Construction & & 0.08 & & 0.05 & & 0.096 \\
\hline Trade and transport & & 0.08 & & 0.06 & & 0.226 \\
\hline Services & & 0.27 & & 0.11 & & 0.000 \\
\hline Media, finance, real estate & & 0.14 & & 0.14 & & 0.921 \\
\hline Administration, education, health & & 0.10 & & 0.35 & & 0.000 \\
\hline
\end{tabular}

Source. SOEP 2004-2013. 


\subsection{The effect of job loss on the willingness to take risks}

In the following, we present OLS estimations of our empirical model (1). The corresponding results are presented in Table 2. We find a significantly negative effect of experiencing job loss due to plant closure on GRA when controlling for the year of the interview of $t=0$ only (Column 2.1). We can thus conclude that the treatment effect does not originate from time trends in risk aversion. Improving the comparability of treatment group and control group by adding controls for pre-treatment socio-demographic characteristics only marginally affects the size of the job loss coefficient (Column 2.2). The same applies to enlarging the model by further controls for parallel life events accompanying job loss (Column 2.3) as well as pretreatment job characteristics (Column 2.4). In sum, the differences in pre-treatment characteristics described in the previous section seem rather unimportant for the identification of the average treatment effect. Altogether, the results presented in Table 2 strongly support our first hypothesis, suggesting that job loss reduces GRA, i.e. increases absolute risk aversion. Beyond the purpose of our study, we find that another life event, separation, increases willingness to take risks.

Subjective survey items like GRA may undergo a structural change when the event of interest affects the general answering behaviour of survey participants. Hence, the effect does not necessarily need to reflect an actual change in the willingness to take risk, but rather results from a change in the participant's mood. To test this notion, we add additional subjective covariates to model (1) that may be affected by mood effects, but are unrelated to our dependent variable, namely the individual change in worries about environmental protection, maintaining peace and crime in Germany. As none of the listed items changes the estimation results, we do not find evidence for a structural survey bias. 
Table 2: OLS estimation of the effect of job loss on risk tolerance

\begin{tabular}{|c|c|c|c|c|c|c|c|}
\hline \multirow[b]{2}{*}{ Job loss between $t=-1$ and $\mathrm{t}=0$} & $(2.1)$ & \multicolumn{2}{|c|}{$(2.2)$} & \multicolumn{2}{|c|}{ (2.3) } & \multicolumn{2}{|c|}{$(2.4)$} \\
\hline & $-0.292^{* *}(0.142)$ & $-0.311^{* *}$ & $(0.142)$ & $-0.328^{* *}$ & $(0.145)$ & $-0.326^{* *}$ & $(0.145)$ \\
\hline \multicolumn{8}{|l|}{ Pre-treatment socio-demographics } \\
\hline Age in years & & 0.001 & $(0.001)$ & 0.002 & $(0.001)$ & 0.002 & $(0.002)$ \\
\hline Monthly HH income (log) & & -0.025 & $(0.030)$ & -0.026 & $(0.030)$ & -0.002 & $(0.034)$ \\
\hline \multicolumn{8}{|l|}{ ISCED Level (ref. level 4) } \\
\hline Level 1 & & 0.272 & $(0.191)$ & 0.275 & $(0.191)$ & 0.248 & $(0.193)$ \\
\hline Level 2 & & $0.128^{* *}$ & $(0.057)$ & $0.130^{* *}$ & $(0.057)$ & $0.104^{*}$ & $(0.059)$ \\
\hline Level 3 & & 0.068 & $(0.041)$ & $0.070^{*}$ & $(0.041)$ & 0.057 & $(0.042)$ \\
\hline Level 5 & & 0.047 & $(0.051)$ & 0.046 & $(0.051)$ & 0.043 & $(0.052)$ \\
\hline Level 6 & & 0.018 & $(0.043)$ & 0.019 & $(0.043)$ & 0.034 & $(0.046)$ \\
\hline Years of unemployment & & -0.011 & $(0.011)$ & -0.012 & $(0.011)$ & -0.011 & $(0.011)$ \\
\hline Local unemployment rate (\%) & & -0.004 & $(0.004)$ & -0.004 & $(0.004)$ & -0.004 & $(0.004)$ \\
\hline Men & & $0.041^{*}$ & $(0.022)$ & $0.043^{*}$ & $(0.023)$ & $0.056^{* *}$ & $(0.028)$ \\
\hline Child in $\mathrm{HH}$ & & $0.060^{* *}$ & $(0.026)$ & $0.060^{* *}$ & $(0.026)$ & $0.065^{* *}$ & $(0.028)$ \\
\hline Married & & 0.037 & $(0.027)$ & 0.038 & $(0.028)$ & 0.034 & $(0.028)$ \\
\hline Migration background & & $0.097^{* *}$ & $(0.047)$ & $0.099^{* *}$ & $(0.047)$ & $0.083^{*}$ & $(0.048)$ \\
\hline East Germany & & 0.049 & $(0.039)$ & 0.051 & $(0.039)$ & 0.051 & $(0.040)$ \\
\hline \multicolumn{8}{|l|}{ Parallel life events } \\
\hline New job & & & & 0.018 & $(0.037)$ & 0.029 & $(0.037)$ \\
\hline Divorce & & & & -0.124 & $(0.095)$ & -0.122 & $(0.095)$ \\
\hline Separation & & & & $0.224^{* * *}$ & $(0.061)$ & $0.226^{* * *}$ & $(0.061)$ \\
\hline Death of spouse & & & & 0.098 & $(0.287)$ & 0.100 & $(0.287)$ \\
\hline Marriage & & & & 0.006 & $(0.059)$ & 0.005 & $(0.059)$ \\
\hline Child birth & & & & 0.004 & $(0.065)$ & 0.004 & $(0.065)$ \\
\hline Move (change of flat/house) & & & & -0.041 & $(0.090)$ & -0.036 & $(0.090)$ \\
\hline \multicolumn{8}{|l|}{ Pre-treatment job characteristics } \\
\hline Gross hourly wage (Euros) & & & & & & -0.001 & $(0.002)$ \\
\hline Tenure in years & & & & & & 0.001 & $(0.001)$ \\
\hline \multicolumn{8}{|l|}{ Level of occ. autonomy (ref. level 3) } \\
\hline Level 1 & & & & & & 0.034 & $(0.050)$ \\
\hline Level 2 & & & & & & 0.010 & $(0.033)$ \\
\hline Level 4 & & & & & & -0.015 & $(0.033)$ \\
\hline Level 5 & & & & & & -0.027 & $(0.056)$ \\
\hline Company size up to 20 Emp. & & & & & & -0.033 & $(0.034)$ \\
\hline Company size more than 200 Emp. & & & & & & 0.000 & $(0.000)$ \\
\hline Weekly working hours & & & & & & 0.004 & $(0.026)$ \\
\hline Part-time contract & & & & & & $-0.004^{* *}$ & $(0.002)$ \\
\hline Public sector & & & & & & -0.049 & $(0.042)$ \\
\hline \multicolumn{8}{|l|}{ Sector of industry (ref. services) } \\
\hline Extraction, Exploitation & & & & & & 0.004 & $(0.034)$ \\
\hline Production & & & & & & 0.007 & $(0.068)$ \\
\hline Construction & & & & & & 0.009 & $(0.044)$ \\
\hline Trade, transport & & & & & & 0.009 & $(0.063)$ \\
\hline Media, finance, real estate & & & & & & -0.040 & $(0.059)$ \\
\hline Administration, education, health & & & & & & -0.053 & $(0.047)$ \\
\hline Year dummies & yes & \multicolumn{2}{|c|}{ yes } & \multicolumn{2}{|c|}{ yes } & \multicolumn{2}{|c|}{ yes } \\
\hline Constant & $0.355^{* * *}(0.029)$ & $0.215^{* * *}$ & $(0.051)$ & $0.203^{* * *}$ & $(0.052)$ & $0.219^{* * *}$ & $(0.066)$ \\
\hline Observations & 37,700 & \multicolumn{2}{|c|}{37,700} & \multicolumn{2}{|c|}{37,700} & \multicolumn{2}{|c|}{37,700} \\
\hline Adjusted R² & 0.053 & 0.05 & & 0.05 & & 0.05 & \\
\hline
\end{tabular}

Source. SOEP 2004-2013.

Note. The table presents OLS estimates of the change in GRA between $t=-2$ and $t=0 .{ }^{*} p<0.1,{ }^{* *} p<0.05$, ${ }^{* * *} p<0.01$. Robust standard errors in parentheses. The reference period is 2012, the reference group are employed not experiencing an involuntary job loss with average age, tenure, years in unemployment, local unemployment rate, hourly gross wage, level of autonomy and weekly working hours as well as ISCED level 4. Household $(\mathrm{HH})$ income weighted by $\mathrm{OECD}$ equivalent weights. 
We repeat estimating the model with all of the controls (1) for age and gender subgroups separately in order to test whether some of those amplify our results in particular (Table 3). As the initial sample, all subgroups show a negative sign of the treatment effect. While age groups hardy vary in the size of the effect, the gender gap is larger, suggesting men respond somewhat stronger to job loss than women. However, job loss andgender interaction effects in an estimation with the whole sample do not imply statistical significance for this gap.

Table 3. Subgroup results for the effect of job loss on risk tolerance

\begin{tabular}{lc}
\hline & $\begin{array}{c}\text { OLS estimate of } \\
\text { job loss between } t=-1 \text { and } t=0\end{array}$ \\
\hline (2.4) the whole sample & $-0.326^{* *}(0.145)$ \\
(3.1) age $\leq 44$ years & $-0.353^{*}(0.198)$ \\
(3.2) age $\geq 45$ years & $-0.261 \quad(0.210)$ \\
(3.3) women only & $-0.187 \quad(0.226)$ \\
(3.4) men only & $-0.421^{* *}(0.187)$ \\
\hline \hline
\end{tabular}

Source. SOEP 2004-2013.

Note. ${ }^{*} p<0.1,{ }^{* *} p<0.05,{ }^{* * *} p<0.01$. Robust standard errors in parentheses. The dependent variable is the change in general willingness to take risks. Controls are specified as in Table 2, Column 2.4. 44 is the sample median in age.

Complete results are presented in the Appendix, Table A1.

Further analyses reveal the importance of limiting the treatment group to workers who have lost their jobs for the reason of plant closure. Including any dismissal by employer substantially increases the coefficient of job loss on the willingness to take risks compared to Table 2. Depending on the respective specification of (1), the $\beta$-coefficient for the broadly defined treatment group is either slightly above or below zero, but always statistically insignificant. In line with our theoretical considerations, losing work may not take people by surprise who are dismissed for personal reasons and they may not lose much income in the wake of the event as they are more likely to receive low earnings. This can in principle explain why our results differ from those of Sahm (2012).

\subsection{Anticipation and reversion}

As companies get into trouble before they close (plants), workers will perceive an increase in the risk of job loss and start to adjust absolute risk aversion before the actual closure (Hypothesis 2). We therefore expect decreasing willingness to take risks between $t=-2$ and $t=-1$ with the treated. To test this notion, we redefine the dependent variable as the change in GRA between $t=-2$ and $t=-1$ and estimate the full model (1) again. Similarly, we test the assumption of no anticipation of job loss before $t=-2$ by repeating our estimation of the 
full model for the change in GRA between $t=-3$ and $t=-2$. Figure 1 displays the treatment effects of these analyses, including the previous estimate of the impact of job loss in the change in GRA from $t=-2$ to $t=0$ as a yardstick. In line with Hypothesis 2, increasing uncertainty on the eve of job loss decreases the willingness to take risks from $t=-2$ to $t=-1$ $(p=0.067)$. In contrast, we do not observe a significant and substantial effect of future job loss on the change in GRA from $t=-3$ to $t=-2$, suggesting that the risk attitude of treatment and control group both follow a common trend before the event.

As described in Section 1, life events like very rare disasters change the perception of the respective risk and thus increase risk aversion permanently. To test whether this applies to job loss as well, we estimate the model (1) again for the change in GRA between $t=-2$ and the second interview after the event has taken place, $t=1$ (i.e. approximately 1 to 2 years after job loss). This produces no significant effect of job loss, suggesting that the increase in risk aversion until $t=0$ is completely reversed afterwards. Experiencing job loss does not seem to increase its perception in the future.

Figure 1. Anticipation and reversion effects of job loss on risk tolerance

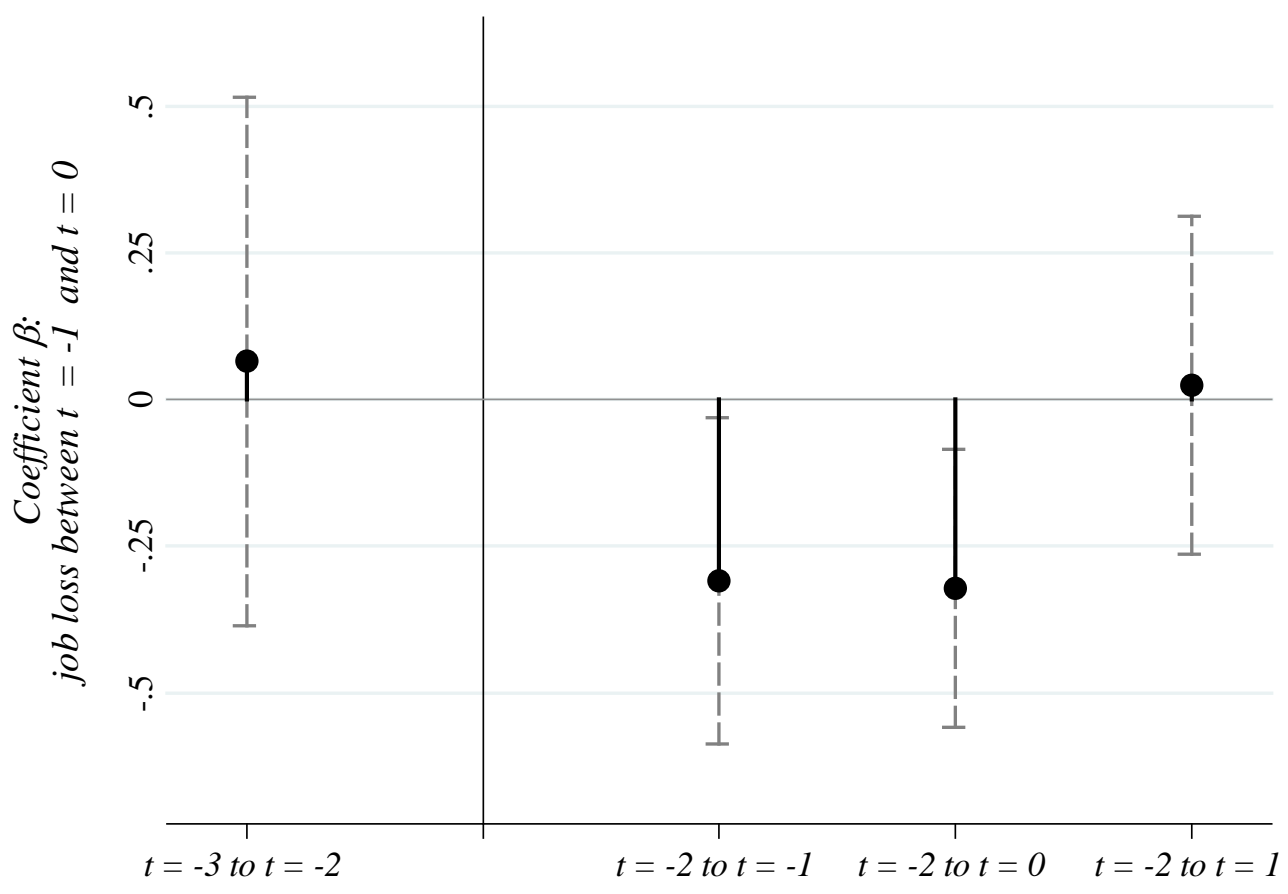

Source. SOEP 2004-2013.

Note. The figure illustrates the timeline of treatment effects obtained by running separate estimations of changes in GRA from different reference points in time between $t=-3$ and $t=1$ to $t=-2$. Droplines denote effect sizes. Whiskers denote $90 \%$ confidence intervals. Note that the $\beta$-coefficients are predicted values based on the model specification presented in Column 2.4 of Table 2 (full set of controls). Complete results of the underlying estimations are presented in Table A2 in the Appendix. 


\subsection{High-skilled versus low-skilled workers}

Throughout the whole analysis, we have assumed that the loss of current income and shattered future income expectations are the main reasons why job loss may alter risk-taking. As a check in this direction, Hypothesis 4 predicts that high-skilled workers (h-type) may respond more strongly to an exogenous job loss than low-skilled workers (l-type). We therefore return to the estimation of the change of GRA between $t=-2$ and $t=0$ as dependent variable and estimate separately the effects of interactions of the job loss variable with indicators of individual productivity and proxies for skills.

Interacting job loss and pre-treatment gross hourly wage, as introduced by (2), yields the strongest support for Hypothesis 4 (Column 4.1 of Table 4). At a hypothetical wage of zero euros, losing work increases $\triangle G R A$ though not significantly. Each additional euro earned per hour before job loss changes the effect of job loss on GRA significantly by -0.036 points. Further checks reveal that the linear specification of this relationship seems reasonable. Thus, job loss reduces GRA by -0.271 points ( -0.325 points) at the median (mean) wage of 12.99 euros (14.51 euros).

Similarly, the GRAs of highly educated workers and workers with high pre-treatment occupational autonomy (as further $h$-type proxies) respond somewhat more negatively to job loss than the GRAs of the respective l-types (Columns 4.2 and 4.3). However, these differences are not statistically significant (Wald-test for linear combination of $\beta_{1}-\left(\beta_{2}+\beta_{3}\right)$ yield $p=0.529$ (education) and $p=0.459$ (autonomy)). These possible differences might reflect the role of income again and point to non-wage characteristics like status and identity (education and autonomy as proxies for occupational position). 
Table 4. Estimation by level of skill

\begin{tabular}{|c|c|c|c|}
\hline & $\begin{array}{c}\text { (4.1) } \\
\text { by hourly } \\
\text { wage }\end{array}$ & $\begin{array}{c}\text { (4.2) } \\
\text { by } \\
\text { education }\end{array}$ & $\begin{array}{c}\text { (4.3) } \\
\text { by level of } \\
\text { autonomy }\end{array}$ \\
\hline Job loss & $\begin{array}{l}0.197 \\
(0.321)\end{array}$ & & \\
\hline Gross hourly wage & $\begin{array}{r}-0.001 \\
(0.002)\end{array}$ & & \\
\hline Job loss $\times$ gross hourly wage & $\begin{array}{l}-0.036^{* *} \\
(0.016)\end{array}$ & & \\
\hline Job loss $\times h$-type $\left(\beta_{1}\right)$ & & $\begin{array}{c}-0.388^{*} \\
(0.207)\end{array}$ & $\begin{array}{l}-0.416^{* * *} \\
(0.161)\end{array}$ \\
\hline Job loss $\times$ l-type $\left(\beta_{2}\right)$ & & $\begin{array}{l}-0.252 \\
(0.189)\end{array}$ & $\begin{array}{c}-0.214 \\
(0.235)\end{array}$ \\
\hline l-type $\left(\beta_{3}\right)$ & & $\begin{array}{l}0.036 \\
(0.027)\end{array}$ & $\begin{array}{l}0.017 \\
(0.030)\end{array}$ \\
\hline $\begin{array}{l}\text { Controls: year dummies, socio-demographics, } \\
\text { parallel shocks, job characteristics }\end{array}$ & yes & yes & yes \\
\hline Constant & $\begin{array}{l}0.266^{* * *} \\
(0.082)\end{array}$ & $\begin{array}{l}0.241^{* * *} \\
(0.060)\end{array}$ & $\begin{array}{l}0.214^{* * *} \\
(0.066)\end{array}$ \\
\hline $\begin{array}{l}\text { Observations } \\
\text { Adjusted } \mathrm{R}^{2}\end{array}$ & $\begin{array}{c}37,700 \\
0.055\end{array}$ & $\begin{array}{c}37,700 \\
0.055\end{array}$ & $\begin{array}{c}37,700 \\
0.055\end{array}$ \\
\hline
\end{tabular}

Source. SOEP 2004-2013.

Note. ${ }^{*} p<0.1,{ }^{* *} p<0.05,{ }^{* * *} p<0.01$. Robust standard errors in parentheses. Hourly wage calculated by gross monthly labour income and actual weekly working hours (in Euros).

Complete results of the underlying estimations are presented in Table A3 in the Appendix.

\subsection{Employment status after job loss and the behavioural validity of stated risk attitude}

Workers' behaviour after job loss allows us to discuss the behavioural validity of our findings on the stated willingness. Those individuals who change GRA most in response to job loss should also be interested in reducing the damage as soon as possible by finding a new job. Workers' who are observed as reemployed at some early point in time after job loss may thus have reduced willingness to take risks in particular. One might object that having found a job balances the negative consequences of job loss, which is why reemployed people might have readjusted their willingness to take risks, but this may be much more relevant in the long-run than in the short-run (see also Section 5.3). At the beginning of a new employment spell, workers have to survive probation (up to 0.5 years in Germany), are employed on a fixedterm basis only, implying that their future employment stability and incomes are still at risk.

The time interval between job loss and the next SOEP interview is six months on average in our sample. This should be sufficient for most workers to get at least one offer to take up a new employment. In fact, the majority of workers have even started a new regular job in the meantime (133 treated observations), whereas smaller groups are still registered as 
unemployed (66) or do anything else (40, e.g. marginal employment). Estimating interaction effects of job loss and these three states based on model (1) reveals that the reemployed have reduced their willingness to take risks significantly more than workers who are still unemployed. As this result also holds for subgroups of relatively low educated workers and relatively low wage earners (as measured before job loss), it does not seem to reflect the highskilled-low-skilled difference of the previous Section 5.4 again. It rather points to a selfselection of workers into reemployment who have reduced their willingness to take risks particularly.

The smaller group of unemployed workers who have not accepted a job offer six months after job loss does not show any negative effect of job loss on GRA (the interaction effect of job loss and being unemployed is positive in all model specifications, but statistically insignificant). This points to a selection of workers into lasting unemployment who are not described accurately by the assumptions we have made in Section 2. For instance, if there exists a small group of workers with increasing absolute risk aversion in income (IARA), they will not reduce their willingness to take risks in response to job loss and are hence ready to stay unemployed for a longer time than the average worker while waiting for a good job match.

As a further check of the behavioural validity of our results, we calculate the impact of the individual change in GRA between $t=-2$ and $t=0$ on the job search duration of the treated. A parametric survival time regression model is estimated using a Weibull distribution with the start of regular part-time or fulltime employment as exit event of interest. Individuals who retire, take part in training schemes or are marginally employed after job loss are excluded from the analysis, because it is not clear whether they actually search for a regular job. Additionally, we do not consider observations of workers who do not report an exact start date of their new employment or report more than 60 months of unemployment. Altogether, we obtain 187 spells out of our initial sample of 239. 154 report the exit event. To control for demand effects on the probability of job finding after job loss, we control for education (ISCED level) and pre-treatment $(t=-2)$ gross hourly wage. In addition, we include gender as explaining variable. Men might feel pushed more to search for a new job because of their breadwinner identity. As shown in Table A4, $\Delta G R A$ between $t=-2$ and $t=0$ is negatively related to the probability of job finding, i.e. the more it reduces in response to job loss the quicker people are observed as reemployed. Figure 2 illustrates the predicted survival rates when GRA changes by $0,-1$ or -2 after job loss. A reduction in GRA by one (two) point(s) 
reduces the expected time in unemployment by approximately half a month (one month) compared to a zero change. ${ }^{6}$ In sum, we find evidence in support of the view that those workers who adjust risk attitude in particular in response to job loss try to reduce the associated damage as soon as possible by searching intensely for a new job.

Figure 2. Survival rates depending on the individual change in GRA

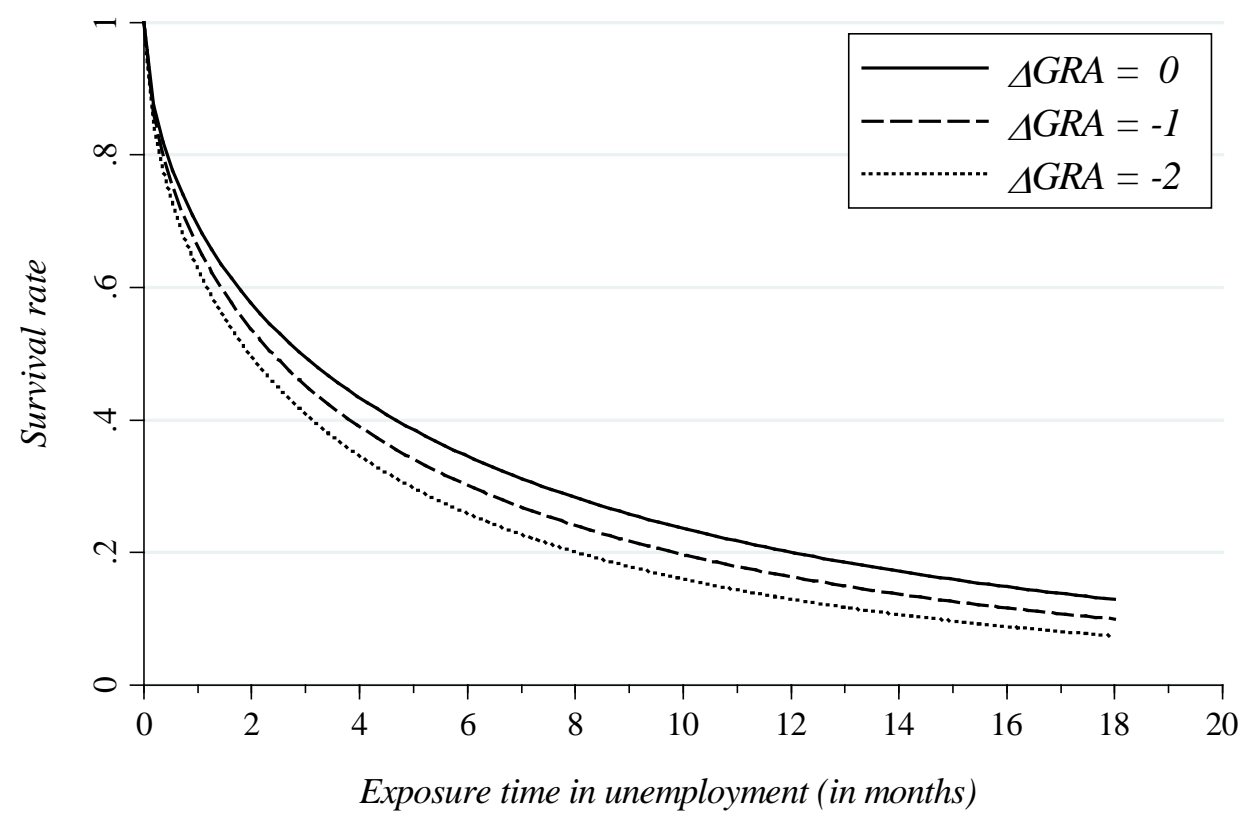

Source. SOEP 2004-2013.

Note. Predicted survival rates for $\triangle G R A=0, \triangle G R A=-1$ and $\triangle G R A=-2$, based on the model specification displayed in Column (4.3) of Table A4.

\subsection{Robustness checks}

In this section, we analyse possible threats to the validity of our identifying assumption, according to which job losses triggered by plant closures hit workers exogenously. A first issue to consider is that of small firms. When the failing business employs a very few people only, the single employee can influence the firms' survival. We therefore run our estimations again based on samples excluding employees of small firms stepwise (below five / below ten / below twenty employees). Compared to the initial estimations presented up to here, the effects of job loss on the willingness to take risks slightly increases in size (while staying

\footnotetext{
${ }^{6}$ As we find anticipation on the eve of job loss, people may start searching for a new job before the event ultimately occurs. A negative anticipation effect ( $\triangle$ GRA from $t=-2$ to $t=-1$ ) should thus expedite reemployment. In fact, repeating our analysis of job finding for $\Delta$ GRA from $t=-2$ to $t=-1$ as explaining variable yields this result.
} 
statistically significant) the more we exclude small firms. Thus, the more the exogeneity assumption is reasonable, the stronger are our results.

If related to risk attitudes, self-selection out of the firm before job loss might take place as we have seen that people may often anticipate plant closure from a certain point in time onwards (Section 5.3). It is a priori not clear into which direction such a selection leads. Assume workers realise at some point in time that the probability of a plant closure increases. People who respond by leaving the firm take the risks of immediate unemployment and job search as well as the risk of uncertain characteristics associated with a potential new job and might thus be relatively risk-prone. However, workers who stay in a firm that is on the rocks take the increasing risk of future unemployment and job search, which could also reflect high willingness to take risks. These two forces work in opposite directions, which could explain why pre-treatment GRA does not vary significantly between treatment and control group (Table 1 in Section 5.1). To analyse this insight further, we estimate the probability to experience a job loss triggered by plant closure starting from $t=-2$ in about one to two years conditioned on the willingness to take risks in $t=-2$. As some of the individual characteristics documented in Table 1 differ on average between treatment and control group, we also consider the full set of socio-demographics and job characteristics in this part of the analysis. Columns A5.1 and A5.2 in Table A5 in the Appendix document the corresponding probit estimation results. They hardly point to any selection into plant closure. Neither the level of the willingness to take risks nor other variables explains the probability of experiencing this reason for job loss in the near future, except some of the sector of industry dummies.

Applying the same probit estimations to the probability of experiencing any dismissal other than plant closure in the next two years supports the conclusion from the regression results that those terminations of employment are rather endogenous, which is in line with the results of Sahm (2012). Workers are the more likely to be dismissed the higher their willingness to take risks, age and number of years they spent unemployed in the past as well as the lower their level of education (Columns A5.3 and A5.5 in Table A5). In contrast, tenure, working hours, overall income and labour earnings decrease the probability of being dismissed in the near future. As many observables are related to other types of dismissal, selection on unobservables may also be a big issue here. It is hence a reasonable strategy to focus on plant closures only, although the number of observations is not very high. 


\subsection{Economic significance of the job loss effect on the willingness to take risks}

To further assess the economic meaningfulness of our findings, we compare the marginal effect of GRA on different economic decisions with the change in GRA caused by loss of job. In so doing, we can clarify whether the results potentially translate into a meaningful change in behaviour under uncertainty. Table 5 lists marginal effects of GRA on different economic decisions which have been identified in the literature. Hereinafter, a male worker who has adjusted GRA by -0.421 in response to job loss according to Table 3 serves as an example for our results.

According to Bonin et al. (2007) an increase in GRA of one point increases the monthly earning by $1.3 \%$. Therefore, in case of a job loss the reduction in GRA of -0.421 for men could resolve in a reduction in monthly wages by $0.5 \%(-0.421 \times 0.013)$. The marginal effect of GRA for the probability of being public sector employed identified by Pfeifer (2010) is $-0.8 \%$ by a given average probability of $32.0 \%$, a job loss would translate in an increasing probability to work in the public sector by $0.33 \%$-points $(-0.421 \times-0.008)$. A bigger effect can be expected for everyday decisions examined by Dohmen et al. (2011). A job loss could reduce the average probability of investments in stocks by $3.5 \%(-0.421 \times 0.029 / 0.341)$, of doing sports by 3.9\% and of smoking by 5.3\%. Caliendo et al. (2014) estimate an average probability to enter self-employment within one year of $1.1 \%$. This transition probability decreases by $0.02 \%$-points when GRA reduces by one point. Straightforward, when a job loss reduces the GRA of men by -0.421 , the probability to start one one's business decreases by $0.008 \%$-points which equals a relative drop in probability of $0.7 \%$. Another effect can be expected with respect to migration. Jaeger et al. (2010) estimate a marginal effect of GRA on the decision to migrate within the next five years by $0.26 \%$-points for a given average probability of 5.8\%. A job loss thus causes a reduction of the migration probability for males by $0.0026 \times-0.421=-0.1 \%$-points or by $2 \%$ of the average probability to migrate in the next five years. 
Table 5. Marginal effects of GRA in the literature

\begin{tabular}{llcc}
\hline Study & Dependent variable & $\begin{array}{c}\text { Average } \\
\text { probability } \\
\text { (in percent) }\end{array}$ & $\begin{array}{c}\text { Marginal } \\
\text { Effect } \\
\text { (in percentage points) }\end{array}$ \\
\hline Bonin et al. (2007) & Monthly earnings & & 1.3 \\
Jaeger et al. (2010) & Migration within next five years & 5.8 & 0.3 \\
Pfeifer (2010) & Being public sector employed & 32.0 & -0.8 \\
Dohmen et al. (2011) & Investment in stocks & 34.1 & 2.9 \\
& Doing active sports & 66.2 & 3.1 \\
& Smoking & 29.4 & 0.02 \\
\hline \hline
\end{tabular}

Note. As GRA is included in a non-linear manner in Caliendo et al. (2014), marginal effect is given for GRA equal to 5. All studies estimate a binary choice model, except Bonin et al. (2007). Marginal effect in Bonin et al. (2007) is a semi-elasticity and given in percent.

\section{Conclusions}

The principle possibility of job loss produces the most important income risk to most workers. Our results show that an increase in this risk reduces the willingness to take other risks. They thus correspond to recent findings of the research on similar background risks like disasters that imply an analogous change in risk aversion. However, the impacts of a rare disaster and the more common loss of employment may have different origins. Since we find the risktaking effect of job loss to be of a transitory nature only, it does not seem to come from a general change in the individual perception of this specific risk, as it has been discussed with respect to natural disasters (e.g. Cameron and Shah 2015). Instead, we find strong evidence that the income shock associated with job loss changes risk attitude for some time.

Our findings do not match those of the study that is related most closely to ours and does not reveal an effect of job loss on risk-taking (Sahm 2012). In principle, this might originate from the different countries analysed or the different direct measures of risk attitude applied, but we suspect the composition of the treatment groups is crucial here. We would also be not able to measure a significant effect if our treated included all dismissed workers like that of Sahm (2012), instead of being limited to losses of work for the reason of plant closure. People who are dismissed for personal reasons might have been able to affect the risk of job loss and are thus not surprised in the case that job loss occurs. As a consequence, they do not modify risk attitude. 
The GRA as a directly measured risk attitude responds clearly to the negative shock of loss of work. Whether this maps into decision-making in various contexts cannot be documented per se, because behavioural changes can be hampered by inertia (Brunnermeier and Nagel 2008) or other dominant factors. At least on the labour market, however, our results are reflected in workers' decisions as they accept job offers according to the change job loss has caused in their risk attitude. The stronger workers' willingness to take risks responds to the event, the quicker they are observed as reemployed, probably to the end of reducing the income loss associated with job loss.

The fact that the GRA measure we use responds to job loss has two methodological implications. Firstly, research on the impact of risk attitude on any outcome cannot assume this measure to be exogenously given like a stable personality trait. Reverse causality and third variable bias can in principle concern such analyses. Secondly, the overall pattern we document is very consistent with the view that the GRA measures absolute risk aversion or, in other words, a local risk preference. GRA changes as background risk in the utility function is altered by the (forthcoming) calamity and it returns to its initial level as the consequences of job loss are removed. In the absence of contrary theoretical foundations of the GRA, this speaks in favour of using the survey item as inverse measure of ARA. It also implies that our findings should not be misinterpreted as evidence for unstable general risk preferences, which are reflected by the shape of the utility function. Quite the contrary, they are well compatible with expected utility reasoning on the impact of job loss on the willingness to take risks. 


\section{References}

Arulampalam, Wiji, Paul Gregg, and Mary Gregory (2001): “Unemployment scarring”, The Economic Journal 111(475), pp. F577-F584.

BBSR - Federal Institute for Research on Building Urban Affairs and Spatial Development (2015): INKAR: Indicators and Maps for Urban Affairs and Spatial Development, http://www.inkar.de/.

Becker, Anke, Thomas Deckers, Thomas Dohmen, Armin Falk, and Fabian Kosse (2012): "The relationship between economic preferences and psychological personality measures”, Annual Review of Economics 4, pp. 453-478.

Bombardini, Matilde and Francesco Trebbi (2012): "Risk aversion and expected utility theory: an experiment with large and small stakes", Journal of the European Economic Association 10(6), pp. 1348-1399.

Bonin, Holger, Thomas Dohmen, Armin Falk, David Huffman, and Uwe Sunde (2007): "Cross-sectional earnings risk and occupational sorting: the role of risk attitudes", Labour Economics 14(6), pp. 926-937.

Brachert, Matthias and Walter Hyll (2014): On the stability of preferences: repercussions of entrepreneurship on risk attitudes, IWH Discussion Paper No. 2014,5.

Brunnermeier, Markus K and Stefan Nagel (2008): "Do wealth fluctuations generate timevarying risk aversion? Micro-evidence on individuals' asset allocation”, The American Economic Review 98(3), pp. 713-736.

Caliendo, Marco, Frank M. Fossen, and Alexander S. Kritikos (2014): "Personality characteristics and the decisions to become and stay self-employed", Small Business Economics 42, pp. 787-814.

Callen, Michael, Mohammad Isaqzadeh, James D. Long, and Charles Sprenger (2014): "Violence and risk preference: experimental evidence from Afghanistan", American Economic Review 104(1), pp. 123-148.

Cameron, Lisa and Manisha Shah (2015): "Risk-taking behaviour in the wake of natural disasters”, Journal of Human Resources 50(2), pp. 484-515.

Cesarini, David, Magnus Johannesson, Paul Lichtenstein, Örjan Sandewall, and Björn Wallace (2010): “Genetic variation in financial decision-making”, Journal of Finance 65(5), pp. 1725-1754.

Charness, Gary, Uri Gneezy, and Alex Imas (2013): "Experimental methods: eliciting risk preferences”, Journal of Economic Behavior \& Organization 87, pp. 43-51.

Dohmen, Thomas, Armin Falk, David Huffman, Uwe Sunde, Jürgen Schupp, and Gert G. Wagner (2011): "Individual risk attitudes: measurement, determinants, and behavioral consequences”, Journal of the European Economic Association 9(3), pp. 522-550.

Dohmen, Thomas, Armin Falk, David Huffman, and Uwe Sunde (2012): "The intergenerational transmission of risk and trust attitudes", Review of Economic Studies 79, pp. 645-677.

Dohmen, Thomas, Armin Falk, Bart Golsteyn, David Huffman, and Uwe Sunde (2015a): "Risk attitudes across the life course", The Economic Journal forthcoming. 
Dohmen, Thomas, Hartmut Lehmann, and Norberto Pignatti (2015b): “Time-varying individual risk attitudes over the great recession: a comparison of Germany and Ukraine”, Journal of Comparative Economics forthcoming.

Eeckhoudt, Louis, Christian Gollier, and Harris Schlesinger (1996): "Changes in background risk and risk taking behavior”, Econometrica 64(3), pp. 683-689.

Fossen, Frank M. and Daniela Glocker (2014): Stated and revealed heterogeneous risk preferences in educational choice, Freie Universität Berlin School of Business \& Economics Discussion Paper No. 2014/03.

Goebel, Jan, Christian Krekel, Tim Tiefenbach, and Nicolas R. Ziebarth (2015): "How natural disasters can affect environmental concerns, risk aversion, and even politics: evidence from Fukushima and three European countries”, Journal of Population Economics 28(4), pp. 1137-1180.

Görlitz, Katja and Marcus Tamm (2015): Parenthood and risk preferences, IZA Discussion Paper No. 8947.

Guiso, Luigi and Monica Paiella (2008): "Risk aversion, wealth, and background risk”, Journal of the European Economic Association 6(6), pp. 1109-1150.

Harrati, Amal (2014): "Characterizing the genetic influences on risk aversion", Biodemography and Social Biology 60, pp. 185-198.

Haushofer, Johannes and Ernst Fehr (2014): “On the psychology of poverty”, Science 344, pp. 862-867.

Hetschko, Clemens, Andreas Knabe, and Ronnie Schöb (2014): “Changing identity: retiring from unemployment”, The Economic Journal 124(575), pp. 149-166.

Jaeger, David A, Thomas Dohmen, Armin Falk, David Huffman, Uwe Sunde, and Holger Bonin (2010): “Direct evidence on risk attitudes and migration”, The Review of Economics and Statistics 92(August), pp. 684-689.

Kassenboehmer, Sonja C. and John P. Haisken-DeNew (2009): "You're fired! The causal negative effect of entry unemployment on life satisfaction", The Economic Journal 119(536), pp. 448-462.

Kihlstrom, Richard E., David Romer, and Steve Williams (1981): "Risk aversion with random initial wealth”, Econometrica 49(4), pp. 911-920.

Kimball, Miles S. (1993): “Standard risk aversion”, Econometrica 61(3), pp. 589-611.

Kunze, Lars and Nicolai Suppa (2014): Bowling alone or bowling at all? The effect of unemployment on social participation, Ruhr Economic Papers No. 510.

Malmendier, U. and S. Nagel (2011): "Depression babies: do macroeconomic experiences affect risk taking?”, The Quarterly Journal of Economics 126(1), pp. 373-416.

Marcus, Jan (2013): "The effect of unemployment on the mental health of spouses - Evidence from plant closures in Germany”, Journal of Health Economics 32(3), pp. 546-558.

Mata, Rui, Robin Hau, Andreas Papassotiropoulos, and Ralph Hertwig (2012): "DAT1 polymorphism is associated with risk taking in the balloon analogue risk task (BART)", PLOS ONE 7(6).

Nachman, David C (1982): "Preservation of “more risk averse” under expectations”, Journal of Economic Theory 28(2), pp. 361-368. 
Pannenberg, Markus (2010): "Risk attitudes and reservation wages of unemployed workers: evidence from panel data”, Economics Letters 106(3), pp. 223-226.

Pfeifer, Christian (2010): “Risk aversion and sorting into public sector employment”, German Economic Review 12(1), pp. 85-99.

Post, Thierry, Martijn J. Van Den Assem, Guido Baltussen, and Richard H. Thaler (2008): "Deal or no deal ? Decision making under risk in a large-payoff game show", American Economic Review 98(1), pp. 38-71.

Pratt, John W and Richard J Zeckhauser (1987): “Proper risk aversion”, Econometrica 55(1), pp. 143-154.

Sahm, Claudia (2012): “How much does risk tolerance change?”, Quarterly Journal of Finance 2(4).

Schmitz, Hendrik (2011): "Why are the unemployed in worse health? The causal effect of unemployment on health”, Labour Economics 18(1), pp. 71-78.

Schurer, Stefanie (2015): Lifecycle patterns in the socioeconomic gradient of risk preferences, IZA Discussion Paper No. 8821.

Skriabikova, Olga J., Thomas Dohmen, and Ben Kriechel (2014): "New evidence on the relationship between risk attitudes and self-employment”, Labour Economics 30, pp. 176-184.

SOEP - Socio-Economic Panel (2015): SOEP: Data for years 1984-2013, version 30, doi: 10.5684/soep.v30.

Wagner, Gert G., Joachim R. Frick, and Jürgen Schupp (2007): “The German SocioEconomic Panel Study (SOEP) - Scope, evolution and enhancements”, Schmollers Jahrbuch 127, pp. 139-169. 
Appendix

Table A1. OLS estimations of subgroup analysis

\begin{tabular}{|c|c|c|c|c|c|c|c|c|}
\hline \multirow{2}{*}{$\begin{array}{l}\text { Subgroup } \\
\text { Job loss between } t=-1 \text { and } t=0\end{array}$} & \multicolumn{2}{|c|}{ Age $\leq 44$} & \multicolumn{2}{|c|}{ Age $>44$} & \multicolumn{2}{|c|}{ Women only } & \multicolumn{2}{|c|}{ Men only } \\
\hline & $-0.353^{*}$ & $(0.198)$ & -0.261 & $(0.210)$ & -0.187 & $(0.226)$ & $-0.421^{* *}$ & $(0.187)$ \\
\hline \multicolumn{9}{|l|}{ Pre-treatment socio-demographics } \\
\hline Age in years & & & & & 0.001 & $(0.002)$ & 0.002 & $(0.002)$ \\
\hline Monthly HH income (log) & 0.011 & $(0.051)$ & -0.012 & $(0.046)$ & -0.029 & $(0.051)$ & 0.013 & $(0.048)$ \\
\hline \multicolumn{9}{|l|}{ ISCED Level (ref. level 4) } \\
\hline Level 1 & 0.245 & $(0.277)$ & 0.262 & $(0.267)$ & 0.325 & $(0.332)$ & 0.213 & $(0.238)$ \\
\hline Level 2 & 0.087 & $(0.079)$ & 0.123 & $(0.093)$ & 0.142 & $(0.089)$ & 0.082 & $(0.079)$ \\
\hline Level 3 & 0.074 & $(0.052)$ & 0.032 & $(0.075)$ & 0.074 & $(0.059)$ & 0.040 & $(0.061)$ \\
\hline Level 5 & 0.041 & $(0.067)$ & 0.035 & $(0.086)$ & 0.084 & $(0.077)$ & 0.016 & $(0.072)$ \\
\hline Level 6 & 0.041 & $(0.059)$ & 0.014 & $(0.077)$ & 0.047 & $(0.066)$ & 0.023 & $(0.064)$ \\
\hline Years of unemployment & -0.016 & $(0.018)$ & -0.010 & $(0.015)$ & -0.018 & $(0.016)$ & 0.001 & $(0.016)$ \\
\hline Local unemployment rate (\%) & -0.006 & $(0.006)$ & -0.002 & $(0.006)$ & -0.000 & $(0.007)$ & -0.007 & $(0.006)$ \\
\hline Men & 0.012 & $(0.039)$ & $0.098^{* *}$ & $(0.041)$ & & & & \\
\hline Child in $\mathrm{HH}$ & $0.081_{* * *}^{* *}$ & $(0.041)$ & 0.056 & $(0.042)$ & 0.058 & $(0.043)$ & $0.071^{*}$ & $(0.037)$ \\
\hline Married & $0.079^{* *}$ & $(0.039)$ & -0.022 & $(0.039)$ & 0.016 & $(0.041)$ & 0.057 & $(0.039)$ \\
\hline Migration background & 0.060 & $(0.066)$ & 0.100 & $(0.070)$ & 0.084 & $(0.073)$ & 0.081 & $(0.064)$ \\
\hline East Germany & 0.057 & $(0.058)$ & 0.053 & $(0.055)$ & 0.032 & $(0.059)$ & 0.069 & $(0.054)$ \\
\hline \multicolumn{9}{|l|}{ Parallel life events } \\
\hline New job & 0.046 & $(0.044)$ & -0.004 & $(0.069)$ & 0.019 & $(0.059)$ & 0.043 & $(0.048)$ \\
\hline Divorce & -0.188 & $(0.123)$ & -0.038 & $(0.149)$ & $-0.365^{* * *}$ & $(0.133)$ & 0.086 & $(0.134)$ \\
\hline Separation & $0.349^{* * *}$ & $(0.071)$ & -0.099 & $(0.121)$ & $0.156^{*}$ & $(0.087)$ & $0.301^{* * *}$ & $(0.085)$ \\
\hline Death of spouse & 0.027 & (1.159) & 0.121 & $(0.269)$ & 0.123 & $(0.357)$ & 0.071 & $(0.475)$ \\
\hline Marriage & 0.049 & $(0.067)$ & -0.101 & $(0.126)$ & -0.081 & $(0.090)$ & 0.067 & $(0.077)$ \\
\hline Child birth & 0.018 & $(0.066)$ & -0.360 & $(0.399)$ & -0.274 & $(0.268)$ & 0.025 & $(0.067)$ \\
\hline Move & -0.080 & $(0.099)$ & 0.155 & $(0.207)$ & -0.134 & $(0.142)$ & 0.039 & $(0.112)$ \\
\hline \multicolumn{9}{|l|}{ Pre-treatment job characteristics } \\
\hline Gross hourly wage (Euros) & 0.002 & $(0.003)$ & -0.003 & $(0.002)$ & 0.004 & $(0.003)$ & -0.003 & $(0.002)$ \\
\hline Tenure in years & -0.002 & $(0.003)$ & 0.001 & $(0.002)$ & 0.001 & $(0.002)$ & 0.001 & $(0.002)$ \\
\hline \multicolumn{9}{|l|}{ Level of occ. autonomy (ref. level 3) } \\
\hline Level 1 & 0.096 & $(0.071)$ & -0.029 & $(0.069)$ & -0.022 & $(0.080)$ & 0.085 & $(0.065)$ \\
\hline Level 2 & 0.043 & $(0.044)$ & -0.029 & $(0.049)$ & -0.036 & $(0.049)$ & 0.063 & $(0.045)$ \\
\hline Level 4 & -0.038 & $(0.047)$ & 0.004 & $(0.046)$ & -0.050 & $(0.052)$ & 0.024 & $(0.043)$ \\
\hline Level 5 & 0.025 & $(0.088)$ & -0.044 & $(0.073)$ & -0.052 & $(0.094)$ & 0.010 & $(0.071)$ \\
\hline Company size up to $20 \mathrm{Emp}$. & -0.027 & $(0.037)$ & 0.029 & $(0.037)$ & 0.002 & $(0.049)$ & -0.067 & $(0.047)$ \\
\hline Company size more than 200 Emp. & $-0.006^{* *}$ & $(0.002)$ & -0.002 & $(0.002)$ & 0.038 & $(0.040)$ & -0.020 & $(0.035)$ \\
\hline Weekly working hours & $-0.146^{* *}$ & $(0.061)$ & 0.032 & $(0.057)$ & $-0.005^{*}$ & $(0.003)$ & -0.003 & $(0.002)$ \\
\hline Part time contract & 0.059 & $(0.048)$ & -0.042 & $(0.048)$ & -0.053 & $(0.054)$ & -0.061 & (0.095) \\
\hline Public sector & -0.027 & $(0.037)$ & 0.029 & $(0.037)$ & -0.008 & $(0.049)$ & 0.010 & $(0.048)$ \\
\hline \multicolumn{9}{|l|}{ Sector of industry (ref. Services) } \\
\hline Extraction, Exploitation & -0.020 & $(0.093)$ & 0.046 & $(0.100)$ & 0.011 & $(0.151)$ & -0.005 & $(0.084)$ \\
\hline Production & -0.006 & $(0.058)$ & 0.038 & $(0.066)$ & 0.041 & $(0.067)$ & -0.015 & $(0.062)$ \\
\hline Construction & -0.006 & $(0.084)$ & 0.036 & $(0.095)$ & -0.107 & $(0.119)$ & 0.009 & $(0.078)$ \\
\hline Trade, transport & -0.041 & $(0.082)$ & -0.026 & $(0.087)$ & -0.044 & $(0.103)$ & -0.055 & $(0.078)$ \\
\hline Media, finance, real estate & -0.085 & $(0.063)$ & -0.002 & $(0.073)$ & -0.078 & $(0.068)$ & -0.047 & $(0.068)$ \\
\hline Administ., education, health & -0.059 & $(0.064)$ & 0.055 & $(0.072)$ & -0.016 & $(0.064)$ & -0.007 & $(0.073)$ \\
\hline Year dummies & \multicolumn{2}{|c|}{ yes } & \multicolumn{2}{|c|}{ yes } & \multicolumn{2}{|c|}{ yes } & \multicolumn{2}{|c|}{ yes } \\
\hline Constant & $0.212^{* *}$ & $(0.087)$ & $0.246^{* *}$ & $(0.113)$ & $0.259^{* * *}$ & $(0.094)$ & $0.243^{* * *}$ & $(0.094)$ \\
\hline Observations & \multicolumn{2}{|c|}{18,940} & \multicolumn{2}{|c|}{18,760} & \multicolumn{2}{|c|}{16,602} & \multicolumn{2}{|c|}{21,098} \\
\hline R-squared & \multicolumn{2}{|c|}{0.051} & 0.0 & & 0.05 & & 0.05 & \\
\hline
\end{tabular}

Source. SOEP 2004-2013.

Note. The table presents OLS estimates of the change in GRA for certain subgroups indicated by the first column. ${ }^{*} p<0.1,{ }^{* *} p<0.05,{ }^{* * *} p<0.01$. Robust standard errors in parentheses. The reference group exhibits the average age, tenure, actual working hours, net labour/household income, and local unemployment rate. It is female, is not living with children in the same household, is not married, its ISCED level of education is 4 and is fulltime employed. Household $(\mathrm{HH})$ income weighted by OECD equivalent weights. 
Table A2. OLS estimations of anticipation and reversion of a job loss on GRA

\begin{tabular}{|c|c|c|c|c|c|c|c|c|}
\hline \multirow{2}{*}{$\begin{array}{l}\Delta \text { GRA between } \\
\text { Job loss between } t=-1 \text { and } t=0\end{array}$} & \multicolumn{2}{|c|}{$t=-3$ and $t=-2$} & \multicolumn{2}{|c|}{$t=-2$ and $t=-1$} & \multicolumn{2}{|c|}{$t=-2$ and $\mathrm{t}=0$} & \multicolumn{2}{|c|}{$t=-2$ and $t=1$} \\
\hline & 0.065 & $(0.274)$ & $-0.309^{*}$ & $(0.169)$ & $-0.322^{* *}$ & $(0.144)$ & 0.024 & $(0.175)$ \\
\hline \multicolumn{9}{|l|}{ Pre-treatment socio-demographics } \\
\hline Age in years & 0.003 & $(0.003)$ & 0.000 & $(0.002)$ & 0.002 & $(0.002)$ & -0.000 & $(0.002)$ \\
\hline Monthly HH income (log) & -0.038 & $(0.055)$ & -0.011 & $(0.040)$ & -0.002 & $(0.034)$ & 0.064 & $(0.044)$ \\
\hline \multicolumn{9}{|l|}{ ISCED Level (ref. level 4) } \\
\hline Level 1 & 0.000 & $(0.394)$ & -0.025 & $(0.269)$ & 0.248 & $(0.193)$ & 0.148 & $(0.252)$ \\
\hline Level 2 & 0.049 & $(0.098)$ & 0.079 & $(0.070)$ & $0.104^{*}$ & $(0.059)$ & -0.013 & $(0.076)$ \\
\hline Level 3 & 0.036 & $(0.067)$ & 0.020 & $(0.049)$ & 0.057 & $(0.042)$ & -0.007 & $(0.053)$ \\
\hline Level 5 & 0.011 & $(0.083)$ & 0.006 & $(0.060)$ & 0.043 & $(0.052)$ & -0.023 & $(0.064)$ \\
\hline Level 6 & 0.039 & $(0.073)$ & 0.018 & $(0.053)$ & 0.034 & $(0.046)$ & -0.077 & $(0.057)$ \\
\hline Years of unemployment & -0.017 & $(0.018)$ & -0.009 & $(0.014)$ & -0.011 & $(0.011)$ & 0.014 & $(0.015)$ \\
\hline Local unemployment rate (\%) & -0.001 & $(0.008)$ & $-0.010^{*}$ & $(0.006)$ & -0.004 & $(0.004)$ & -0.007 & $(0.006)$ \\
\hline Men & -0.001 & $(0.045)$ & 0.015 & $(0.033)$ & $0.056^{* *}$ & $(0.028)$ & $0.090^{* *}$ & $(0.036)$ \\
\hline Child in $\mathrm{HH}$ & -0.001 & $(0.044)$ & 0.026 & $(0.032)$ & $0.065^{* *}$ & $(0.028)$ & $0.074^{* *}$ & $(0.036)$ \\
\hline Married & -0.011 & $(0.044)$ & 0.001 & $(0.032)$ & 0.034 & $(0.028)$ & 0.038 & $(0.035)$ \\
\hline Migration background & 0.082 & $(0.078)$ & -0.012 & $(0.057)$ & $0.083^{*}$ & $(0.048)$ & -0.004 & $(0.062)$ \\
\hline East Germany & -0.010 & $(0.060)$ & 0.060 & $(0.045)$ & 0.051 & $(0.040)$ & $0.096^{*}$ & $(0.050)$ \\
\hline \multicolumn{9}{|l|}{ Parallel life events } \\
\hline New job & 0.017 & $(0.060)$ & 0.035 & $(0.044)$ & 0.029 & $(0.037)$ & 0.027 & $(0.049)$ \\
\hline Divorce & $-0.277^{*}$ & $(0.156)$ & -0.120 & $(0.111)$ & -0.122 & $(0.095)$ & -0.156 & $(0.116)$ \\
\hline Separation & $0.232^{* *}$ & $(0.099)$ & $0.169^{* *}$ & $(0.072)$ & $0.226^{* * *}$ & $(0.061)$ & 0.108 & $(0.080)$ \\
\hline Death of spouse & 0.401 & $(0.422)$ & -0.037 & $(0.304)$ & 0.100 & $(0.287)$ & 0.183 & $(0.364)$ \\
\hline Marriage & 0.031 & $(0.101)$ & 0.001 & $(0.069)$ & 0.005 & $(0.059)$ & 0.085 & $(0.077)$ \\
\hline Child birth & 0.004 & $(0.118)$ & 0.041 & $(0.079)$ & 0.004 & $(0.065)$ & $0.184^{* *}$ & $(0.084)$ \\
\hline Move & $-0.355^{* *}$ & $(0.161)$ & 0.047 & $(0.104)$ & -0.036 & $(0.090)$ & $-0.183^{*}$ & $(0.111)$ \\
\hline \multicolumn{9}{|l|}{ Pre-treatment job characteristics } \\
\hline Gross hourly wage (Euros) & 0.000 & $(0.003)$ & -0.003 & $(0.002)$ & -0.001 & $(0.002)$ & $-0.006^{* *}$ & $(0.002)$ \\
\hline Tenure in years & 0.000 & $(0.002)$ & 0.001 & $(0.002)$ & 0.001 & $(0.001)$ & 0.002 & $(0.002)$ \\
\hline \multicolumn{9}{|l|}{ Level of occ. autonomy (ref. level 3) } \\
\hline Level 1 & -0.017 & $(0.084)$ & 0.023 & $(0.059)$ & 0.034 & $(0.050)$ & 0.054 & $(0.063)$ \\
\hline Level 2 & 0.014 & $(0.052)$ & -0.003 & $(0.038)$ & 0.010 & $(0.033)$ & $-0.115^{* * *}$ & $(0.041)$ \\
\hline Level 4 & 0.039 & $(0.053)$ & -0.006 & $(0.0$ & -0.015 & $(0.033)$ & -0.015 & $(0.041)$ \\
\hline Level 5 & 0.067 & $(0.092)$ & 0.048 & & -0.027 & $(0.056)$ & -0.071 & $(0.070)$ \\
\hline Company size up to 20 Emp. & -0.047 & $(0.055)$ & -0.035 & $(0.040)$ & -0.033 & $(0.034)$ & 0.009 & $(0.043)$ \\
\hline Company size more than $200 \mathrm{Emp}$. & 0.016 & $(0.043)$ & -0.001 & $(0.031)$ & 0.004 & $(0.026)$ & 0.044 & $(0.033)$ \\
\hline Weekly working hours & -0.003 & $(0.003)$ & $-0.005^{* *}$ & $(0.002)$ & $-0.004^{* *}$ & $(0.002)$ & -0.003 & $(0.002)$ \\
\hline Part time contract & -0.100 & $(0.066)$ & $-0.101^{* *}$ & $(0.048)$ & -0.049 & $(0.042)$ & -0.045 & $(0.053)$ \\
\hline Public sector & -0.025 & $(0.055)$ & 0.014 & $(0.040)$ & 0.004 & $(0.034)$ & 0.043 & $(0.044)$ \\
\hline \multicolumn{9}{|l|}{ Sector of industry (ref. Services) } \\
\hline Extraction, Exploitation & 0.015 & $(0.105)$ & 0.022 & $(0.079)$ & 0.007 & $(0.068)$ & 0.114 & $(0.086)$ \\
\hline Production & 0.032 & $(0.072)$ & 0.020 & $(0.051)$ & 0.009 & $(0.044)$ & 0.090 & $(0.055)$ \\
\hline Construction & 0.006 & $(0.097)$ & 0.026 & $(0.073)$ & 0.009 & $(0.063)$ & $0.140^{*}$ & $(0.079)$ \\
\hline Trade, transport & 0.071 & $(0.098)$ & 0.012 & $(0.071)$ & -0.040 & $(0.059)$ & 0.031 & $(0.076)$ \\
\hline Media, finance, real estate & 0.113 & $(0.077)$ & -0.019 & $(0.055)$ & -0.053 & $(0.047)$ & -0.078 & $(0.059)$ \\
\hline Administ., education, health & 0.077 & $(0.077)$ & 0.002 & $(0.055)$ & -0.005 & $(0.048)$ & 0.008 & $(0.060)$ \\
\hline Year dummies & \multicolumn{2}{|c|}{ yes } & \multicolumn{2}{|c|}{ yes } & \multicolumn{2}{|c|}{ yes } & \multicolumn{2}{|c|}{ yes } \\
\hline Constant & $-0.557^{* * *}$ & $(0.102)$ & 0.123 & $(0.076)$ & $0.219^{* * *}$ & $(0.066)$ & $-0.193^{* *}$ & $(0.083)$ \\
\hline Observations & \multicolumn{2}{|c|}{13,702} & \multicolumn{2}{|c|}{25,602} & \multicolumn{2}{|c|}{37,700} & \multicolumn{2}{|c|}{23,457} \\
\hline R-squared & \multicolumn{2}{|c|}{0.048} & 0.0 & & 0.0 & & 0.08 & \\
\hline
\end{tabular}

Source. SOEP 2004-2013.

Note. The table presents OLS estimates of the change in GRA between the period indicated by the first column. ${ }^{*} p<0.1,{ }^{* *} p<0.05,{ }^{* * *} p<0.01$. Robust standard errors in parentheses. The reference group exhibits the average age, tenure, actual working hours, net labour/household income, and local unemployment rate. It is female, is not living with children in the same household, is not married, its ISCED level of education is 4 and is fulltime employed. Household (HH) income weighted by OECD equivalent weights. 
Table A3. OLS estimations by level of skill

\begin{tabular}{|c|c|c|c|c|c|c|}
\hline \multirow{3}{*}{$\begin{array}{l}\text { Job loss between } t=-1 \text { and } t=0 \\
\times \text { Gross hourly wage (Euros) }\end{array}$} & \multicolumn{2}{|c|}{ By hourly wage } & \multicolumn{2}{|c|}{ By level of education } & \multicolumn{2}{|c|}{ By level of autonomy } \\
\hline & 0.197 & $(0.321)$ & & & & \\
\hline & $-0.036^{* *}$ & $(0.016)$ & & & & \\
\hline × high skill level (binary) & & & $-0.388^{*}$ & $(0.207)$ & $-0.416^{* * *}$ & $(0.161)$ \\
\hline × low skill level (binary) & & & -0.252 & $(0.189)$ & -0.214 & $(0.235)$ \\
\hline No job loss $\times$ low skill level (binary) & & & 0.036 & $(0.027)$ & 0.017 & $(0.030)$ \\
\hline \multicolumn{7}{|l|}{ Pre-treatment socio-demographics } \\
\hline Age in years & 0.002 & $(0.002)$ & 0.002 & $(0.002)$ & 0.002 & $(0.002)$ \\
\hline Monthly HH income (log) & -0.002 & $(0.034)$ & -0.002 & $(0.034)$ & -0.005 & $(0.034)$ \\
\hline \multicolumn{7}{|l|}{ ISCED Level (ref. level 4) } \\
\hline Level 1 & 0.248 & $(0.193)$ & & & 0.257 & $(0.192)$ \\
\hline Level 2 & $0.104^{*}$ & $(0.059)$ & & & $0.108^{*}$ & $(0.058)$ \\
\hline Level 3 & 0.056 & $(0.042)$ & & & 0.057 & $(0.042)$ \\
\hline Level 5 & 0.043 & $(0.052)$ & & & 0.041 & $(0.052)$ \\
\hline Level 6 & 0.034 & $(0.046)$ & & & 0.028 & $(0.044)$ \\
\hline Years of unemployment & -0.011 & $(0.011)$ & -0.010 & $(0.011)$ & -0.010 & $(0.011)$ \\
\hline Local unemployment rate (\%) & -0.004 & $(0.004)$ & -0.004 & $(0.004)$ & -0.004 & $(0.004)$ \\
\hline Men & $0.056^{* *}$ & $(0.028)$ & $0.058^{* *}$ & $(0.028)$ & $0.054^{*}$ & $(0.028)$ \\
\hline Child in $\mathrm{HH}$ & $0.065^{* *}$ & $(0.028)$ & $0.066^{* *}$ & $(0.027)$ & $0.064^{* *}$ & $(0.027)$ \\
\hline Married & 0.034 & $(0.028)$ & 0.034 & $(0.028)$ & 0.034 & $(0.028)$ \\
\hline Migration background & $0.083^{*}$ & $(0.048)$ & $0.089^{*}$ & $(0.048)$ & $0.086^{*}$ & $(0.048)$ \\
\hline East Germany & 0.051 & $(0.040)$ & 0.051 & $(0.039)$ & 0.051 & $(0.040)$ \\
\hline \multicolumn{7}{|l|}{ Parallel life events } \\
\hline New job & 0.030 & $(0.037)$ & 0.030 & $(0.037)$ & 0.030 & $(0.037)$ \\
\hline Divorce & -0.122 & $(0.095)$ & -0.122 & $(0.095)$ & -0.122 & $(0.095)$ \\
\hline Separation & $0.228^{* * *}$ & $(0.061)$ & $0.226^{* * *}$ & $(0.061)$ & $0.226^{* * *}$ & $(0.061)$ \\
\hline Death of spouse & 0.099 & $(0.287)$ & 0.098 & $(0.287)$ & 0.100 & $(0.287)$ \\
\hline Marriage & 0.004 & $(0.059)$ & 0.004 & $(0.059)$ & 0.005 & $(0.059)$ \\
\hline Child birth & 0.003 & $(0.065)$ & 0.003 & $(0.065)$ & 0.004 & $(0.065)$ \\
\hline Move & -0.037 & $(0.090)$ & -0.037 & $(0.090)$ & -0.036 & $(0.090)$ \\
\hline \multicolumn{7}{|l|}{ Pre-treatment job characteristics } \\
\hline Gross hourly wage (Euros) & -0.001 & $(0.002)$ & -0.001 & $(0.002)$ & -0.001 & $(0.002)$ \\
\hline Tenure in years & 0.001 & $(0.001)$ & 0.001 & $(0.001)$ & 0.001 & $(0.001)$ \\
\hline \multicolumn{7}{|l|}{ Level of occ. autonomy (ref. level 3) } \\
\hline Level 1 & 0.033 & $(0.049)$ & 0.047 & $(0.049)$ & & \\
\hline Level 2 & 0.009 & $(0.032)$ & 0.009 & $(0.033)$ & & \\
\hline Level 4 & -0.015 & $(0.032)$ & -0.009 & $(0.031)$ & & \\
\hline Level 5 & -0.028 & $(0.055)$ & -0.023 & $(0.055)$ & & \\
\hline Company size up to $20 \mathrm{Emp}$. & -0.033 & $(0.034)$ & -0.032 & $(0.034)$ & -0.034 & $(0.034)$ \\
\hline Company size more than 200 Emp. & 0.004 & $(0.026)$ & 0.005 & $(0.026)$ & 0.005 & $(0.026)$ \\
\hline Weekly working hours & $-0.004^{* *}$ & $(0.002)$ & $-0.004^{* *}$ & $(0.002)$ & $-0.004^{* *}$ & $(0.002)$ \\
\hline Part time contract & -0.050 & $(0.042)$ & -0.050 & $(0.042)$ & -0.051 & $(0.042)$ \\
\hline Public sector & 0.003 & $(0.034)$ & 0.006 & $(0.034)$ & 0.002 & $(0.034)$ \\
\hline Sector dummies & \multicolumn{2}{|c|}{ yes } & \multicolumn{2}{|c|}{ yes } & \multicolumn{2}{|c|}{ yes } \\
\hline Year dummies & \multicolumn{2}{|c|}{ yes } & \multicolumn{2}{|c|}{ yes } & \multicolumn{2}{|l|}{ yes } \\
\hline Constant & $0.266^{* * *}$ & $(0.082)$ & $0.241^{* * *}$ & $(0.060)$ & $0.214^{* * *}$ & $(0.066)$ \\
\hline Observations & \multicolumn{2}{|c|}{37,700} & \multicolumn{2}{|c|}{37,700} & \multicolumn{2}{|c|}{37,700} \\
\hline R-squared & \multicolumn{2}{|c|}{0.055} & \multicolumn{2}{|c|}{0.055} & \multicolumn{2}{|c|}{0.055} \\
\hline
\end{tabular}

Source. SOEP 2004-2013.

Note. The table presents OLS estimates of the change in GRA. ${ }^{*} p<0.1,{ }^{* *} p<0.05,{ }^{* * *} p<0.01$. Robust standard errors in parentheses. The reference group exhibits the average age, tenure, actual working hours, net labour/household income, and local unemployment rate. It is female, is not living with children in the same household, is not married, its ISCED level of education is 4 and is fulltime employed. Household (HH) income weighted by OECD equivalent weights. Interaction terms between two variables are indicated by „, ×”. 
Table A4. Estimation results of parametric survival time regression

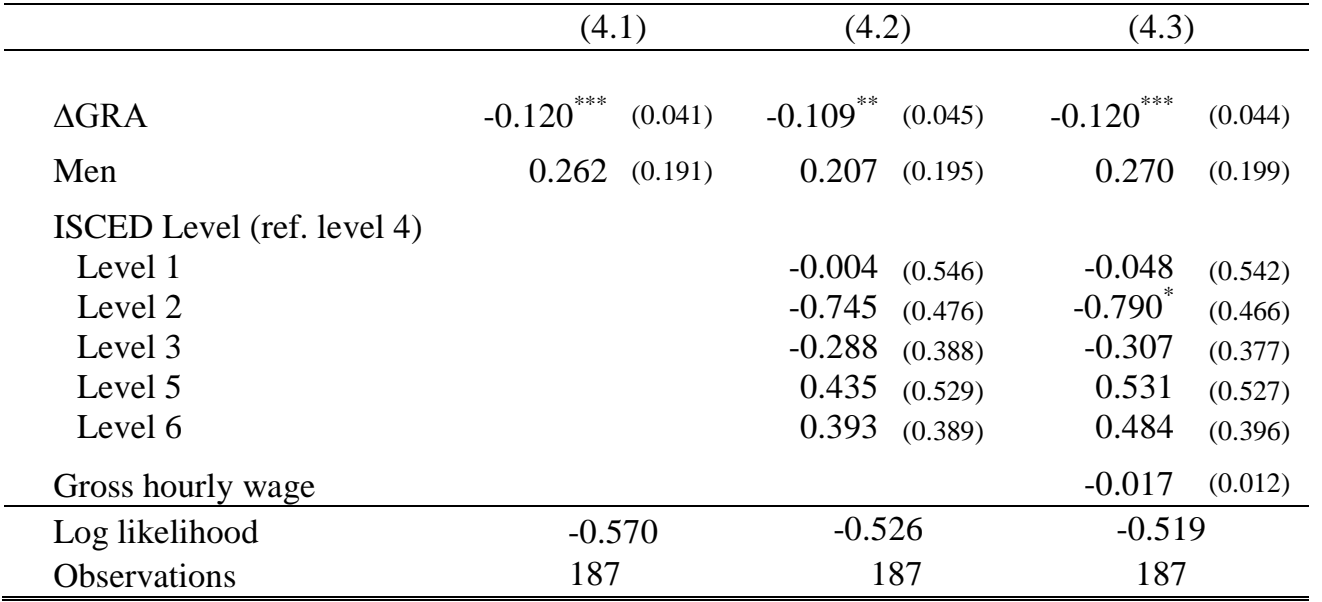

Source. SOEP 2004-2013.

Note. ${ }^{*} p<0.1,{ }^{* *} p<0.05,{ }^{* * *} p<0.01$. Robust standard errors in parentheses. Coefficients reported, not hazard rates. 154 observations report an exit event. ISCED level and gross hourly wage taken in $t=-2$. $\triangle G R A$ denotes change in GRA between $t=-2$ and $t=0$ for column (4.1), (4.2) and (4.3). 
Table A5. The probabilities of future job loss by plant closure and by other kinds of dismissal

\begin{tabular}{|c|c|c|c|c|c|c|c|c|}
\hline \multirow{3}{*}{$\begin{array}{l}\text { Dependent Variable } \\
\text { GRA in } t=-2\end{array}$} & \multicolumn{2}{|c|}{$(5.1)$} & \multicolumn{2}{|c|}{$(5.2)$} & \multicolumn{2}{|c|}{ (5.3) } & \multicolumn{2}{|c|}{ (5.4) } \\
\hline & \multicolumn{4}{|c|}{ Plant closure between $\mathrm{t}=-1$ and $\mathrm{t}=0$} & \multicolumn{4}{|c|}{ Dismissed between $\mathrm{t}=-1$ and $\mathrm{t}=0$} \\
\hline & 0.010 & $(0.011)$ & 0.007 & $(0.012)$ & $0.025^{* * *}$ & $(0.007)$ & $0.032^{* * *}$ & $(0.008)$ \\
\hline \multicolumn{9}{|l|}{ Pre-treatment socio-demographics } \\
\hline Age in years & & & 0.005 & $(0.003)$ & & & $0.015^{* * *}$ & $(0.002)$ \\
\hline Monthly HH income (log) & & & -0.038 & $(0.075)$ & & & $-0.161^{* * *}$ & $(0.052)$ \\
\hline \multicolumn{9}{|l|}{ ISCED Level (ref. level 4) } \\
\hline Level 1 & & & 0.056 & $(0.292)$ & & & $0.349^{* *}$ & $(0.175)$ \\
\hline Level 2 & & & 0.062 & $(0.120)$ & & & 0.056 & $(0.088)$ \\
\hline Level 3 & & & -0.035 & $(0.093)$ & & & 0.054 & $(0.068)$ \\
\hline Level 5 & & & -0.024 & $(0.121)$ & & & 0.095 & $(0.086)$ \\
\hline Level 6 & & & -0.076 & $(0.109)$ & & & 0.041 & $(0.079)$ \\
\hline Years of unemployment & & & -0.001 & $(0.021)$ & & & $0.039^{* * *}$ & $(0.010)$ \\
\hline Local unemployment rate (\%) & & & 0.010 & $(0.010)$ & & & 0.006 & $(0.007)$ \\
\hline Men & & & 0.022 & $(0.063)$ & & & 0.047 & $(0.043)$ \\
\hline Child in $\mathrm{HH}$ & & & 0.016 & $(0.059)$ & & & -0.051 & $(0.041)$ \\
\hline Married & & & 0.044 & $(0.059)$ & & & $-0.075^{*}$ & $(0.040)$ \\
\hline Migration background & & & $0.150^{*}$ & $(0.078)$ & & & $-0.127^{* *}$ & $(0.062)$ \\
\hline East Germany & & & 0.056 & $(0.292)$ & & & $0.349^{* *}$ & $(0.175)$ \\
\hline \multicolumn{9}{|l|}{ Job characteristics in $t=-2$} \\
\hline Gross hourly wage (Euros) & & & -0.012 & $(0.089)$ & & & -0.057 & $(0.061)$ \\
\hline Tenure in years & & & 0.108 & $(0.106)$ & & & 0.031 & $(0.067)$ \\
\hline \multicolumn{9}{|l|}{ Level of occ. autonomy (ref. level 3) } \\
\hline Level 1 & & & -0.041 & $(0.093)$ & & & 0.071 & $(0.058)$ \\
\hline Level 2 & & & 0.096 & $(0.065)$ & & & 0.012 & $(0.046)$ \\
\hline Level 4 & & & 0.014 & $(0.080)$ & & & -0.029 & $(0.061)$ \\
\hline Level 5 & & & -0.253 & $(0.182)$ & & & 0.033 & $(0.128)$ \\
\hline Company size up to $20 \mathrm{Emp}$. & & & 0.091 & $(0.065)$ & & & $0.167^{* * *}$ & $(0.042)$ \\
\hline Company size more than 200 Emp. & & & -0.031 & $(0.059)$ & & & $-0.132^{* * *}$ & $(0.043)$ \\
\hline Weekly working hours & & & 0.000 & $(0.004)$ & & & $-0.023^{* * *}$ & $(0.002)$ \\
\hline Part time contract & & & -0.038 & $(0.094)$ & & & $-0.323^{* * *}$ & $(0.059)$ \\
\hline Public sector & & & $-0.374^{* * *}$ & $(0.100)$ & & & $-0.365^{* * *}$ & $(0.064)$ \\
\hline \multicolumn{9}{|l|}{ Sector of industry (ref. Services) } \\
\hline Extraction, Exploitation & & & $-0.554^{* * *}$ & $(0.173)$ & & & 0.016 & (0.094) \\
\hline Production & & & $-0.235^{* * *}$ & $(0.072)$ & & & 0.028 & $(0.055)$ \\
\hline Construction & & & $-0.207^{* *}$ & $(0.104)$ & & & $0.146^{* *}$ & $(0.070)$ \\
\hline Trade, transport & & & -0.153 & $(0.102)$ & & & 0.045 & $(0.078)$ \\
\hline Media, finance, real estate & & & $-0.214^{* *}$ & $(0.085)$ & & & 0.064 & $(0.062)$ \\
\hline Administ., education, health & & & $-0.444^{* *}$ & $(0.100)$ & & & $-0.109^{*}$ & $(0.064)$ \\
\hline Year dummies & \multicolumn{2}{|c|}{ yes } & \multicolumn{2}{|c|}{ yes } & \multicolumn{2}{|c|}{ yes } & \multicolumn{2}{|c|}{ yes } \\
\hline Constant & $-2.629^{* * *}$ & $(0.078)$ & $-2.367^{* * *}$ & $(0.143)$ & $-2.065^{* * *}$ & $(0.044)$ & $-2.152^{* * *}$ & $(0.101)$ \\
\hline Observations & \multicolumn{2}{|c|}{37,700} & \multicolumn{2}{|c|}{37,700} & \multicolumn{2}{|c|}{38,188} & \multicolumn{2}{|c|}{38,188} \\
\hline Pseudo R-squared & \multicolumn{2}{|c|}{0.004} & \multicolumn{2}{|c|}{0.057} & \multicolumn{2}{|c|}{0.006} & 0.1 & \\
\hline
\end{tabular}

Source. SOEP 2004-2013.

Note. ${ }^{*} p<0.1,{ }^{* *} p<0.05,{ }^{* * *} p<0.01$. Robust standard errors in parentheses. The reference group exhibits the average level of willingness to take risks, age, tenure, actual working hours, net labour/household income, and local unemployment rate. It is female, is not living with children in the same household, is not married, its ISCED level of education is 4 and is fulltime employed. 